Motu Working Paper 21-09

Understanding the Origins of

Populist Political Parties and the Role of External Shocks

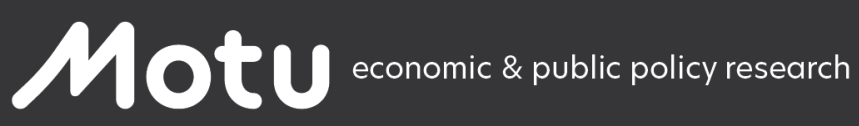

Eugenio Levi, Isabelle Sin, Steven Stillman

August 2021 


\section{Document information}

\section{Author contact details}

Eugenio Levi

Masaryk University

Faculty of Economics and Administration

eugenio.levi@econ.muni.cz

Isabelle Sin

Senior Fellow, Motu Economic and Public Policy Research

izi.sin@motu.org.nz

Steven Stillman

Free University of Bozen-Bolzano

Steven.Stillman@unibz.it

\section{Acknowledgements}

This research was funded by an internal grant from the Free University of Bozen-Bolzano. We thank Massimo Morelli, Federico Boffa, Andreas Steinmayr, Helmut Rainer, Panu Poutvaara, Jack Vowles, as well as seminar participants at CESifo and at the University of Modena and Reggio Emilia and conference participants at the Alpine-Population Workshop, ZEW Workshop on Immigration, Integration and Attitudes, the 10th Annual Conference on Immigration in OECD Countries and the SKILS conference. Stillman also thanks CESifo for hosting him as a visiting fellow.

\section{Disclaimer}

The anonymized census data used in this study was provided by Statistics New Zealand. Access to the data used in this study was provided by Stats NZ under conditions designed to give effect to the security and confidentiality provisions of the Statistics Act 1975. The results presented in this study are the work of the authors, not Stats NZ or individual data suppliers.

\section{Motu Economic and Public Policy Research}

PO Box $24390 \quad$ info@motu.org.nz +64 49394250

Wellington www.motu.org.nz

New Zealand

(C) 2021 Motu Economic and Public Policy Research Trust and the authors. Short extracts, not exceeding two paragraphs, may be quoted provided clear attribution is given. Motu Working Papers are research materials circulated by their authors for purposes of information and discussion. They have not necessarily undergone formal peer review or editorial treatment. ISSN 1176-2667 (Print), ISSN 1177-9047 (Online). 


\section{Abstract}

We use electoral survey data to examine the impact that two large external shocks had on the development of New Zealand First (NZF), one of the oldest populist parties in the OECD. We find that structural reforms, which led to large negative impacts on particular locations, and immigration reforms, which led to large spatially concentrated increases in skilled migration, both increased voting for NZF in its first years of existence. These shocks led to changes in political attitudes and policy preferences and had persistent effects on voting for NZF even twenty years later. Overall, they play an important role in explaining the rise of populism in NZ. Understanding how these shocks led to the development of NZF is particularly relevant for thinking about how populism has been extending its reach in the 2010s.

\section{JEL codes}

D72; P16; H40

\section{Keywords}

Populism; political parties; trade; immigration; shocks. 


\title{
Understanding the Origins of Populist Political Parties and the Role of External Shocks*
}

\author{
Eugenio Levi, Masaryk University \\ Isabelle Sin, Motu Economic and Public Policy Research \\ Steven Stillman, Free University of Bozen-Bolzano, CESifo, IZA
}

July 2021

\begin{abstract}
We use electoral survey data to examine the impact that two large external shocks had on the development of New Zealand First (NZF), one of the oldest populist parties in the OECD. We find that structural reforms, which led to large negative impacts on particular locations, and immigration reforms, which led to large spatially concentrated increases in skilled migration, both increased voting for NZF in its first years of existence. These shocks led to changes in political attitudes and policy preferences and had persistent effects on voting for NZF even twenty years later. Overall, they play an important role in explaining the rise of populism in NZ. Understanding how these shocks led to the development of NZF is particularly relevant for thinking about how populism has been extending its reach in the 2010 s.
\end{abstract}

JEL Codes: D72; P16; H40

Keywords: populism; political parties; trade; structural reforms; immigration; shocks

\footnotetext{
*Contact author: steven.stillman@unibz.it. This research was funded by an internal grant from the Free University of Bozen-Bolzano. We thank Massimo Morelli, Federico Boffa, Andreas Steinmayr, Helmut Rainer, Panu Poutvaara, Jack Vowles, as well as seminar participants at CESifo and at the University of Modena and Reggio Emilia and conference participants at the Alpine-Population Workshop, ZEW Workshop on Immigration, Integration and Attitudes, the 10th Annual Conference on Immigration in OECD Countries and the SKILS conference. Stillman also thanks CESifo for hosting him as a visiting fellow. The anonymized census data used in this study was provided by Statistics New Zealand. Access to the data used in this study was provided by Stats NZ under conditions designed to give effect to the security and confidentiality provisions of the Statistics Act 1975. The results presented in this study are the work of the authors, not Stats NZ or individual data suppliers.
} 


\section{Introduction}

There are many explanations for the success of populist political parties (see Margalit 2019; and Guriev and Papaioannou 2020, for recent reviews). But why have they emerged in the first place? Most populist parties, e.g., UKIP in UK, the Five-Star Movement in Italy, AfD in Germany, and Podemos in Spain, appear almost overnight and then a moment later they are changing the political landscape and obliging mainstream parties to adapt to their rhetoric and priorities (Mudde, 2019). ${ }^{1}$ As populist parties are primarily defined by their anti-elitism, distributional issues are often seen as an important driver of their development (Rodrik 2018). However, it is difficult to escape the feeling that economic and political crises also help explain their emergence. ${ }^{2}$ Moreover, research on populists' communication style point out that crises are a specific and recurring feature of the populist discourse (Moffitt 2016).

There is little empirical evidence on what drives the birth of populist parties, and specifically the role of economic and political shocks in this process. To fill this gap, we examine the impact that two large external shocks had on the initial development of New Zealand First (NZF), a populist and nationalist anti-immigration party with an otherwise centrist agenda founded in 1993, making it one of the oldest populist parties in the OECD. ${ }^{3}$ In the early 1980s, New Zealand (NZ) experienced a large economic crisis, mostly caused by external forces, that led to structural reforms and the opening of free trade. These changes had large negative impacts on particular industries, many of which were geographically concentrated. Later, as part of a gradual shift away from an immigration system based on country-of-origin quotas, the Immigration Reform Act of 1987 was passed, which led to the development of a skilled migration system and large changes in the composition of migrant inflows.

We use electoral survey data to examine the impact that these two shocks had: i) on voting for NZF in its first years of existence; ii) on individual beliefs and political preferences including the supply of and demand for political change; iii) on long-run persistence in voting for NZF; and iv) relative to other factors that encouraged people to vote for NZF. Our use of an electoral survey, as opposed to voting data, allows us to examine the pathways through which these

\footnotetext{
1 Populism in many ways feels like a contagious disease the ends up causing a pandemic.

2 This partly comes for observation. Most populist political parties, especially in the Western world, have emerged after an economic shock: in Europe, a big burst of both left-wing and right-wing populist parties followed the 2008 economic downturn, while a specific role seems to have been played also by the large migration shocks following the 2004 enlargement round of the European Union and the 2015 refugee crisis (Guriev and Papaioannou 2020).

3 As discussed in more detail below, NZF has more in common with right-wing populist parties in Europe than left-wing parties but espouses a relatively soft authoritarian populism (Vowles and Curtin 2020).
} 
shocks affect voting behaviors and heterogeneity in their impacts, as well as to compare their importance to other channels that have been shown to influence populist voting. ${ }^{4}$

Importantly, this survey data contains very localized geographic identifiers that allow us to combine it with five-yearly census data to measure the two shocks, as well as to control for socioeconomic characteristics of each local area. Specifically, we measure the two shocks as: i) the percentage loss in income between 1986 and 1991 in a local area (which we call the "structural reform shock" from now on) and ii) the share of the local population that has immigrated to NZ in the previous five years ("immigration shock"). ${ }^{5}$ We also use these data to build instruments to account for any potential endogeneity of these shocks. For the impact of structural reforms, we use the distribution of 265 industries in an area in 1986 combined with the change in incomes in these industries between 1986 and 1991. And for the impact of immigration, we use detailed information on the country of birth (124 CoBs) of recent immigrants in 1993 and 1996 combined with the distribution of immigrants by CoB in local areas before the reform of the immigration system in 1986. We show below that our instruments are uncorrelated with voting patterns in 1984 prior to the shocks being experienced.

We find that these shocks are positively related with votes for NZF already in 1993 at the electoral district level and that these effects become statistically significant in 1996 after NZ switched its electoral system from First Past the Post (FPP) to Mixed-Member Proportional (MMP) and NZF experienced a doubling in vote share. ${ }^{6}$ If we instead focus on a more natural geography of local labor market areas, which we can do only starting in 1996, we find stronger impacts of the shocks. In our preferred specification using the instruments described above, we find that a 1 percentage-point increase in recent arrivals increases the NZF vote share by 4.8 percentage points and the same size reduction in income caused by structural reforms increases it by 1.3 percentage points relative to an actual vote share of 11 percent. The impact of the immigration shock is found to be entirely driven by increased immigration from Asia and there

4 As shown in Figure 1, responses in the survey closely mirror actual voting behavior and we find similar results when we use official data to measure voting outcomes (available from the authors on request).

5 We measure the structural reform shock between 1986 and 1991 because previous work has shown that this is when the largest industry specific shocks were experienced (Stillman et al. 2010). This paper also shows that findings are similar when 1981 census data is used to measure the baseline situation, but there are several comparability issues when using this older data, in particular, a completely different industry classification is used. 6 As discussed in Riambau et al. (2021), the electoral system was switched because of the results from a binding referendum. We show below that experiencing shocks, in particular the immigration shock, also led to a significant increase in individuals voting to change the electoral system. 
is no impact of these shocks on turnout or voting for other political parties, indicating that there is a specific link between these shocks and populist voting.

To better understand why these shocks led to an increase in populist voting, we next examine their impact on people's political opinions, beliefs, and policy preferences. Consistent with our findings on voting, we find no impact of these shocks on an individual's political position but experiencing either shock leads to an increase in populist attitudes, such as mistrust of the mainstream political parties and preferences for a strong leader. We also find that increased immigration makes people more hostile to immigration and more likely to consider security issues as important. On the other hand, individuals who experience a larger structural reform shock have increased preferences for redistribution, have increased feelings that the economy has been badly managed, and feel that unemployment is a more relevant policy issue. These changes in preferences and beliefs explain around 30 percent of the overall impact of each shock on voting for NZF.

We also provide supporting evidence on whether these shocks led to increased support for populism by changing the attitudes and desires of the voters or by changing the 'supply' of populism via the creation of NZF (Guiso et al. 2017). Consistent with demand side being more important, we find a strong significant impact of having experienced an immigration shock on individual's voting to change the political system in the 1993 referendum that switched the electoral system from FPP to MMP. On the other hand, we do not find an impact of experiencing these shocks on whether NZF was more likely to field candidates in a particular electorate in 1993.

Given that we find these shocks lead to changes in individual preferences and the demand for populism, and that previous work has found that the structural reform shock persists at the local level (Stillman et al. 2010), we examine whether the shocks continue to have an impact on voting for NZF into the future. Importantly, persistent effects on shocks could explain why populist parties survive for long periods and become an embedded part of the political landscape. Examining the impact of these shocks on voting for NZF in the six elections from 1999 to 2014, we find that they continue to influence voting, particular when NZF is in opposition and also when the economy is doing well. We suspect that the latter occurs because NZF does not focus on economic policy and the rhetoric around immigration in NZ is more about the negative impact of inflows on house prices and local amenities rather than on labor markets and hence tends to be more in focus when the economy is doing well (Vowles and Curtin 2020). Overall, the shocks we examine have some long-term memory in them. 
We next examine heterogeneity in the impact of these shocks to better understand the channels underlying the short-run effects. In general, the impact of both shocks is homogeneous across sociodemographic characteristics, suggesting that competition effects do not drive our results. Consistent with previous research that has focused solely on the impact of immigration shocks, we find larger impacts of recent immigration on populist voting in less densely populated places and areas that have less immigration prior to the policy change (Dustmann et al. 2019). Structural reform shocks also have smaller effects in more densely populated areas. This is consistent with urban populations being more flexible and less resistant to change, and also to cultural concerns being more important in rural areas (Di Tella and Rotemberg 2018).

We also examine whether the impact of shocks varies with the preferences and beliefs of individuals. This analysis is merely suggestive as we find that shocks also directly impact these variables. In general, the impact of the immigration shock does not depend on individual preferences and beliefs, but the structural reform shock has a larger impact on individuals with negative views about immigration, preferences for more redistribution, negative feelings about the quality of recent policies, mistrust towards political parties, and positive feelings about Winston Peters, the founder and leader of NZF. These results suggest that the large decline in incomes caused by structural reforms at the end of the ' 80 s translated into the emergence of NZF through its impact on and interaction with anti-immigration and anti-elite attitudes.

Finally, we examine the relevance of different explanations for populism by calculating the partial R-squared associated with different groups of variables that are included in our regressions. In our main model, variation in shocks explains almost 10 percent of the variation in voting for NZF, which is of a similar relevance to the combined effect of individual demographic, social, and economic characteristics. However, in our extended model, it is clear that differences in preferences, beliefs, and opinions are even more important for explaining the variation in populist voting. Overall, we find an important role for shocks in explaining the rise of populism in NZ, and the impact of these shocks both amplify and are amplified by differences in political beliefs and opinions.

Our paper makes a number of important contributions:

First, we bring together two separate strands of an expanding political economy literature on populism. One focuses on the impact of economic shocks on populist voting. Papers have examined the role of globalization, in particular trade with China (Becker et al. 2017; Dippel et al. 2017; Colantone and Stanig 2018a; 2018b; 2019; Alabrese et al. 2019; Dorn et al. 2020), 
macroeconomic shocks (Algan et al. 2017; Dal Bó et al. 2021), and the recent rise in automation (Im et al., 2019, Anelli et al., 2019). The second focuses on the impact of immigration on populist voting (Barone et al. 2016; Halla et al. 2017; Edo et al. 2019; Dustmann et al. 2019; Levi et al. 2020). None of these papers study the joint role of economic and immigration shocks where both come from exogenous sources. This literature has divergent views on whether globalization alone is responsible for the rise of populism in Europe and the US or whether institutional rigidities and a lack of trust are necessary contributors (Guiso et al. 2017; Guiso et al. 2019). Our findings that structural reforms were a key ingredient in the development of NZF along with changes in the immigration system and that experiencing these shocks also led to decreased trust and a desire to change the political system is consistent with the idea that globalization alone is not responsible for rising populism and that political dissatisfaction is also a necessary condition.

Second, we show that immigration and structural reform shocks impact political preferences, beliefs, and opinions, that these political variables are important for explaining populist voting and that having particular preferences, beliefs, and opinions amplify the impact of experiencing shocks. Almost all previous papers take an epidemiological approach and relate geographical patterns in voting to quasi-experimental variation in the spatial distribution of shocks. ${ }^{7}$ This makes it difficult to evaluate the channels through which the shocks impact populist voting. By using electoral survey data combined with spatially distributed shocks, we are able to examine the pathways through which shocks impact voting as well as heterogeneity in impacts. Our results support previous arguments that labor market competition is not the main pathway through which immigration shocks lead to populist voting (e.g., Card et al. 2012; Hainmueller and Hopkins 2014; Margalit 2019). The same appears to be true of shocks driven by structural reforms and increased trade exposure which has not been shown yet in the literature.

Third, a unique aspect of our paper is the focus on the initial years of development of an 'old' populist party. This allows us to examine the persistence of the impact of economic and immigration shocks and understand under what circumstances these shocks have long-run impacts on support for populism. This is particularly important for understanding what we should expect to happen in the future in European countries and the US where the political expression of populism is a more recent phenomenon. Our evidence suggests that while support

7 Exceptions include Burgoon et al. (2019) and Guiso et al. (2017), which both use European Social Survey data to investigate the relation between economic insecurity and votes for populist parties at an individual level, and Moriconi et al. (2019) who use the same data to study the impact of immigration on nationalistic voting. 
for populism fluctuates with both political and economic conditions, it never goes away entirely and under the right combination of conditions tends to reappear in the same locations as in the past. In the end, we find that voters dissatisfied with mainstream parties are still around in the same places even 30 years after the initial events that caused their dissatisfaction.

Fourth, we contribute to a large literature in political science by also evaluating the role of political preferences, beliefs, and opinions on populist voting and how these interact with the economic shocks. In particular, a number of papers show the importance of 'cultural backlash' in explaining populist voting (Norris and Inglehart 2019; Cramer 2016; Hochschild 2016; Gest 2016; Eribon 2018) while others examine the importance of populist attitudes, such as disenchantment with traditional parties and democracy (Mudde 2007; Akkermann et al. 2014; Spruyt et al. 2016). We show that these explanations are indeed relevant for understanding the origins of NZF and that economic and political explanations for populism appear, in fact, to be highly intertwined. ${ }^{8}$

While NZ is a small country at the end of the world, it is a forerunner to many of the current trends affecting OECD countries. In the 1980s, NZ experienced a deep economic crisis that led to structural reform process which significantly decreased government support and increased competition within certain industries. The shock was similar in many ways to the impact that China joining the WTO and now expanding automation had on the rest of the developed world in the 2000/2010s. Similarly, NZ was at the forefront in developing a skilled migration system that had no restrictions on country of origin and led to large inflows of immigrants from culturally distant countries.

The country's populist party, NZF, was formed just before the 1993 election and, by the next in 1996, it acquired a remarkable 13 percent of the vote. Even though it has a fairly centrist policy platform, we show below that it attracts very similar voters in terms of observable characteristics as current populist parties in Europe. Focusing on this case study allows us to investigate the origins of a populist party without confounding effects from the recent global emergence of populism - Trump, Brexit, etc. - and, given that NZF has been part of NZ politics for almost 30 years, to understand why populist parties survive in the face of the general incompetence of their personnel (Funke et al. 2020).

8 Our work is also related to a small literature examining how economic shocks impact political opinions, beliefs, and policy preferences (for example, Ahlquist et al. 2020) as well as that on the political impacts of structural reforms (for example, Alesina et al. 2020). 


\section{Background}

\subsection{New Zealand First}

NZF is in many ways, consistent with its populist traits, the story of Winston Peters, its ongoing leader from its foundation in 1993. Peters was first elected to Parliament in 1978 as a member of the mainstream center-right National party. Like many recent populist leaders, such as Salvini, Farage, Le Pen, Mélenchon, Lafontaine, etc. he has a long-term involvement with politics. From the end of the ' 80 s, he started criticizing National leadership in public on a variety of issues without any clear ideology. His focus on anti-corruption and political accountability rocketed his popularity with polls indicating that over a quarter of NZers were ready to vote for a Winston Peters party. In 1992, he was expelled from the Cabinet and told that he could not stand again as National candidate in his electoral district. In July 1993, only five months before the new general elections, he launched NZF.

As Boston and McLeay (1997) put it, "the party quickly developed an image as being strongly nationalistic, anti-establishment, populist, and mildly protectionist. Its most publicised policy commitments emphasised the need to stop the sale of state assets, limit the sale of NZ land and resources to overseas investors, restrict immigration, protect local industry, and hold politicians more accountable”. Because of an anti-elite stance fueled by disgruntlement toward traditional politics and of the identification of the party with its leader, NZF can clearly be categorized as a populist party. However, unlike most European populist parties that clearly belong to either the left or the right, NZF promotes a mixture of (far-) right and (far-) left policies. It is against big business, unions, and big government, critical of the ' 80 s pro-market reforms and wants NZ to go back to a "golden age" where the country was more isolated from the rest of the world. The organization of the party, as it is typical of populist parties, is very loose and all decisions are left to the central direction of the party.

In 1993, NZF received $8.4 \%$ of the total votes cast and won two seats (out of 99) in NZ's unicameral parliament, which at that point used a first-past-the-post (FPP) electoral system as in the US and UK. In the same election, a binding referendum was held that somewhat surprisingly led to a change in the electoral system from FPP to MMP (mixed-member proportional, see Riambau et al. (2021) for more details). In this new system, political representation is based on the national percentage of the vote received by each party, provided 
that the party reaches a 5 percent threshold. ${ }^{9}$ As the 1996 election approached, NZF increased its anti-immigration stance, with Peters blaming immigrants for "placing a significant strain on education and health services' and 'causing high home mortgage rates'. It ended up getting $13.5 \%$ of the party vote and a corresponding $17 \mathrm{MPs}$. In a very controversial move, the party decided to use its pivotal role in the Parliament to become part of a government with the National party with Peters taking for himself the role of Minister of Treasury.

In Table 1, we show for which parties the initial supporters of NZF previously voted in 1990 (using the electoral survey data described in detail below). The party built up a support base of its own rather than relying on exit flows from a specific mainstream party. While a slight majority of voters in 1996 previously voted for the National party (36\%), many other supporters previously voted for the Labour Party (28\%). If we instead look at the share of individuals who previously voted for other parties in 1990 who then voted for NZF, this picture becomes even clearer. More or less $10 \%$ of the voters of each party in 1990, from the right-wing National to the far-left Alliance switched to voting for NZF in 1996 election. Interestingly, this is true even though Peters was previously a leading member of the National party.

After 1996, NZF never reached the same percentage of votes, ranging from a high of $10.4 \%$ in 2002 to a low of $2.6 \%$ in last election in 2020 (Figure 1). In 2008 and 2020, the party also failed to win a directly elected seat and hence fell out of Parliament entirely. However, thanks to its pivotal role in some years, it succeeded in becoming part of the government again in 2005 and 2017, both times in coalition with the center-left Labour Party. Hence, even though it is in many ways a marginal party in NZ, it has played an important role in helping to set the policy agenda, in particular on immigration policy and on support for older individuals and rural interests.

We show in Appendix 1 Table that similar individuals in terms of observable characteristics voted for NZF in 1996 as for populist parties in Europe in the 2000s. ${ }^{10}$ Both attract votes from older individuals, those with lower level of education and lower incomes, and those living in rural areas. To sum up, NZF positioned itself not far from the political space that other

\footnotetext{
9 In practice, everyone has two votes, one for a local FPP election and the other a party vote. In 1996, sixty-five MPs were chosen based on the first vote while the other 55 were selected from a national list with the total elected (in the local elections and from the list) for each party reflecting only the proportion of party votes received.

10 We use the European Social Survey data for this comparison and define a political party as populist if it scored higher than 7 on the average between the two questions on populism in the 2014 and 2019 waves of the Chapel Hill Expert Survey (see the footnote of the Appendix 1 Table for more details).
} 
European populist parties would later occupy. Not only this is consistent with well-established evidence on who votes for populist parties in Europe and in the US (Norris and Inglehart, 2019), but it also strengthens the argument that investigating NZF is particularly relevant for thinking about how populism has been extending its reach in the 2010s in other Western countries.

\subsection{Brief Economic History of New Zealand}

Up to 1984, NZ had a highly regulated economy, with subsidies for agriculture, protection for industry and a closed capital account. By that time, the country was facing unsustainable fiscal and current account deficits, runaway inflation, and a foreign exchange crisis. This led to widespread recognition that macroeconomic reforms were needed to correct imbalances and reduce inflation, and microeconomic reforms were needed to improve productivity (McMillan 1998). A vast program of reforms later labelled "Rogernomics", after the Labour Finance Minister Roger Douglas who enacted most of them, was implemented.

From 1984 to 1987, the Labour government increasingly deregulated the economy, opened the capital account, and eliminated subsidies to agriculture. Under a re-elected Labour government, between 1987 and 1990 most major publicly owned companies were privatized. In the 1990 election, the National party won on the promise to slow down the pace of the reforms and to steer away from "Rogernomics". However, the party's liberal wing took control after the election and pushed through large reforms to the welfare system and labour market policy. Welfare was scaled back from universal provision to a tightly targeted welfare system (Boston et al. 1999) while labour market regulations, among other things, decentralized the employeremployee bargaining process (Evans et al. 1996).

From 1986 and 1991, real per capita GDP growth averaged $-0.83 \%$ and unemployment rose from $5 \%$ in 1984 to almost $11 \%$ in 1992 . Mean real household income dropped by $4.7 \%$ between 1986 and 1991. The reform process had a particularly strong impact on the manufacturing sector with employment falling by 30\% between 1987 and 1995 (Gibson and Harris 1996). There were also strong negative impacts on employment in the agriculture sector. Stillman et al. (2010) show that the negative impact of these reforms was strongly spatially concentrated because of the geographical distribution of industries and that the reforms had long-run impacts on the labor market in particular communities. We take advantage of the spatial aspect of the impact of these reforms to examine their impact on voting for NZF. 


\subsection{Immigration in New Zealand}

NZ is historically a high immigration country with most migrants settling in the larger cities of Auckland, Wellington, and Christchurch (Maré et al. 2007). In 1986, 15\% of the population was already foreign-born, but immigrants were mostly of European descent ( $49 \%$ of them were British compared with $6 \%$ Asian) as migration up to that point was mainly allowed from traditional source countries along with some low-skill migration from the Pacific Islands. Independent of the economic reforms discussed above, an Immigration Policy Review was held in 1986. This review aimed to develop new policy initiatives that would "enrich the multicultural fabric of New Zealand society through the selection of new settlers principally on the strength of their personal contribution to the future well-being of New Zealand" (Burke, 1986: 10). The ensuing Immigration Act 1987 removed the traditional source country preference for European or Anglo-Saxon countries. The Immigration Amendment Act 1991 then replaced the previous 'occupational priority list' system with a point system.

These Acts combined inverted a previous trend in net migration by increasing arrivals. While between 1980 and 1989 NZ lost a net 122,500 migrants, mainly because of unfavorable economic conditions, from 1990 net migration turned positive even though the economy was still struggling. In 1995, a peak net inflow of 28,500 was reached and by 1996 immigrants were $21 \%$ of the total population. More importantly, there was a large change in the composition of the immigrant population. Specifically, $15 \%$ of the immigrant population was now of Asian descent, with the number of Chinese-born in NZ increasing between 1986 and 1996 from 4,900 to 19,500 , Hong Kong-born from 1,881 to 11,760 , Korean-born from 390 to 12,183 and Taiwan-born from 165 to 10,930 .

\section{Data and Empirical Strategy}

\subsection{Data}

To assess the impact of economic and migration shocks on the emergence of populism, we use data from the New Zealand Election Study (NZES). NZES is a telephone survey that is designed to be representative of the voting population and has been fielded by the University of Auckland since 1990 immediately after each general election. It collects extensive data on opinions about political parties, own politics and voting behaviors, as well as individual and household characteristics. In particular, individuals are asked whether they voted in the election that just occurred, and if yes, for which candidate and party they voted. They are also asked who they voted for in the two previous elections. Whether an individual voted or not is later 
certified by the Electoral Committee and self-reported party votes closely match actual voting patterns in aggregate data (refer to Figure 1). In 1993, 2,232 individuals were surveyed, increasing to 4,113 individuals in 1996.

The main advantage of using the NZES as opposed to using official election data is that it collects a wide range of information on individual characteristics, political opinions, political behaviors, and policy concerns that allow us to examine the channels through which shocks influence voting behavior and examine the importance of other factors that lead individuals to vote for NZF. Importantly, starting in 1996, an individual's place of residence is geocoded to their census meshblock, which is the smallest geographic area defined by Statistics NZ and contain, on average, 150 individuals. We exploit this information to both measure the characteristics of the local area (at the area unit - AU - level which is equivalent to an urban suburb or rural town) and to link individuals to their local labor market area (LMA or commuting zone), which is the natural geography for assessing the political impact of the shocks borne by local communities. Unfortunately, in 1993, we can link individuals only to their electoral district (ED), which reduces the precision of our estimates of the impact of localized shocks. ${ }^{11}$

\subsection{Defining Shocks}

We define two shocks related to the economic history of NZ using the universe of individuallevel observations from the 1986, 1991, and 1996 census. Beyond having access to data on the full population, we also know the meshblock of each household and hence can match individuals perfectly to AUs, LMAs, and EDs. This allows us to measure shocks and local area characteristics with minimal measurement error.

We define the 'structural reform shock' experienced by an individual living in a particular LMA or ED, as the change in average log real income between 1986 and 1991 in that location. We focus on the difference in this five-year period because previous work has shown that this is when the largest industry-specific shocks were experienced (Stillman et al. 2010). Similarly, we define the 'immigration shock' experienced by an individual living in a particular LMA or $\mathrm{ED}$ as the inflow of new migrants in the five years prior to the election being examined as a

11 Papps and Newell (2002) use travel-to-work data from the 1991 census data to define 140 LMAs that are selfcontained commuting zones. In urban areas, LMAs generally encompass the main urban area and an extensive catchment area. In rural areas, LMAs tend to consist of numerous small areas, each centred on a minor service centre. Electoral districts (ED) are updated after each census by a special commission and designed to contain the same number of individuals with only a 5\% permitted variation. Hence, in urban areas they tend to be quite small, while they can be very large in sparsely populated rural areas. 
percentage of the local population at the start of the period (so the 1988-1993 period for the 1993 elections and the 1991-1996 period for the 1996 elections). ${ }^{12}$ As discussed above, during this period the migration inflow was historically large and the ethnic composition of the inflow was a radical departure from previous migration waves (Statistics New Zealand, 2010).

As we assign individuals based on their current location, this will introduce measurement error bias leading towards finding smaller impacts of the economic shocks. The NZES asks individuals how long they have lived in their current community and, in 1996, 70.7\% report living in the same community as ten years earlier when the shocks occurred. Our main results are unaffected if we restrict our analysis to this selected subsample.

Figure 2 shows the spatial distribution of the shocks as well as vote shares for NZF across electoral districts. There appears to be a strong correlation between local areas experiencing a larger structural reform shock and a higher local vote share for NZF. There is less evidence of a relationship between immigrant inflows and voting for NZF. This is unsurprising as immigration is highest in the big cities where voting for NZF is less prevalent.

\subsection{Empirical Strategy}

We start by examining the relationship between the income and immigration shock experienced by an individual and whether they cast their party vote for NZF in the 1993 and 1996 elections. Specifically, we estimate the following regression model by OLS separately using the 1993 and 1996 waves of the NZES linked to the appropriate census data:

$$
\operatorname{VoteNZF_{ij}}=\alpha+\delta \operatorname{ImmSh}_{j}+\lambda I n c S h_{j}+X B+e_{i j}
$$

where $V_{\text {oteNZF }}$ is an indicator for whether individual $i$ living in community $j$ voted for NZF, $I m m S h_{j}$ is the share of recent immigrants in that community, $I n c S h_{j}$ is the mean (log) decline in income experienced between 1986 and 1991 in that community and $\mathrm{X}$ is a vector of control variables that varies across specifications with all regressions including controls for gender, age-group, ethnicity, immigration status, education, employment status, (log) household income, religiousness, and place of residence among big cities (Auckland, Wellington, Christchurch), cities, towns and rural areas. ${ }^{13}$

12 New migrants include all foreign-born individuals who arrived in NZ in the previous five years. As 1993 is not a census year, we use the self-reported number of years spent in NZ for immigrants in the 1996 census to calculate the inflow between 1988 and 1993.

$13 \mathrm{We}$ categorize as religious any individual who attends a religious service at least 2 times a month. Household income is categorical; we impute a continuous measure using the mid-point of each category. 
We begin by focusing on electoral districts (EDs) as our measure of community as this is the most disaggregated geographical information available in the 1993 data. However, the majority of our analysis focuses on the impact of shocks on local labor market areas (LMAs) because, as discussed above, these are a more relevant geographical unit for thinking about how individuals living in an area experience the two shocks we measure. As shocks vary only at the ED or LMA level, standard errors in all models are clustered at the appropriate geographical level.

Beyond LMAs being a more relevant geography, starting in 1996, when we focus on variation at the LMA level, we can also further control for characteristics of the local area (suburb or rural town) where an individual lives. Specifically, we control for the total population, the unemployment and employment rate, the average $(\log )$ individual income, the Gini index, and the percentage of people with different qualifications, in different age groups, who are female, and who are Maori. ${ }^{14}$ In these models, we also control for the ED in which a person resides. In urban areas, LMAs include many EDs, while in rural areas, EDs always overlap with multiple LMAs. Hence, we can always separately identify the impact of being in a particular ED. This is potential important as it controls for any localized political responses to having experienced particular shocks.

Table 2 provides summary statistics for the 1993 and 1996 NZES, as well as our measures of shocks and local area characteristics. We present these for the full samples and for the samples we use in our analysis. In 1993, we drop from our analysis sample 7 people because they are missing gender and 14 because they did not provide information on their electorate. In 1996, we drop from our analysis sample 18 people because they are missing gender and 622 because they did not provide enough information for their address to be matched to a census meshblock. For all other independent variables in our regression, we include dummies for individuals missing the information so they can be included in the analysis. Fortunately, as can be seen in Table 2, the characteristics of the individuals missing locational information are quite similar in general to the overall sample, hence we do not expect this to impact the external validity of our findings even in 1996. Supporting this, we are able to include most of these individuals in our ED level analysis for 1996, and this has little qualitative impact on our results.

14 When we examine the impact on voting in later elections, we interpolate these socio-economic characteristics from the closest censuses: given that in New Zealand there are elections every 3 years and censuses collection every 5 years, there is no election that is far more than 2 years from the census. 
The average individual in the NZES in both 1993 and 1996 lives in an area where nearly 3 percent of the population are immigrants who have arrived in the previous five years. On average, almost half of these new arrivals are from Asia. The average individual also lives in a community which experienced around a 5 percent income decline between 1986 and 1991 . Comparing individual to local characteristics in 1996 makes apparent that participants in the NZES are, on average, older and more educated than the general population. ${ }^{15}$ This is typically found in electoral surveys. As discussed later in the paper, we find very little heterogeneity in the impact of shocks by sociodemographic characteristics, suggesting that this skewness is not important for interpreting out results.

A concern with the regression model outlined above is that shocks could be endogenously determined with voting behavior. For example, immigrants might avoid moving to areas with anti-immigrant sentiments and instead locate in more open-minded areas where populism tends to be less attractive. This endogenous sorting would lead us to underestimate the impact of immigration on populist voting. Similar issues exist when examining the impact of structural reforms. For example, if workers most affected by structural reforms are both more likely to leave a community and to vote for a populist party, this sorting would lead to a downward bias in estimated impact of the structural reform shock. It is also possible that biases could work in the other direction, for example, if factors influencing the severity of the impact of the structural reforms also directly influenced voting preferences a decade later.

In order to address these endogeneity concerns and produce consistent estimates of the impact of immigration and structural reform shocks on voting for NZF, we use an instrumental variable approach. As is well known, new migrants tend to settle in locations where co-nationals from earlier immigration waves already live (Bartel 1989). Hence, we follow the approach originally proposed in Altonji and Card (1991), and used in many subsequent papers, and predict the number of migrants who would move to a local community only because of network effects. Specifically, we calculate

$$
I m \hat{m S h} h_{j t}=\sum_{k} \frac{\lambda_{j k}^{86} I m m S h_{k t}}{\operatorname{Pop}_{j}^{t}}
$$

where $I m m S h_{j t}$ is the predicted share of recent immigrants in location $j$ at time $t$ and is equal to the number of immigrants originating from country $k$ in the five years prior to time $t$ at the

15 This is the case even after using the provided weights that are designed to increase the representativeness of the survey. We use these weights throughout our analyses. The NZES collects household income and the census individual income so these cannot be directly compared. 
national level multiplied by the county of birth distribution in each location in 1986. As we have access to the full population census data, we are able to examine networks at an extremely disaggregated level aggregating over 124 countries of origins.

While this instrument has been used in thousands of past papers, recent work has argued that, if the spatial distribution of immigrant inflows is stable over time, the instrument is likely to be correlated with previous location decisions leading to mis-estimation of the causal impact of recent migration (Jaeger et al. 2018). In our context, the large reform of the immigration system that started in 1987 reduces concerns that new immigrants are drawn to the same areas as past immigrants because of economic fundamentals. Furthermore, prior to the reform, the political debate around immigration in NZ was drastically different, as outflows were larger than inflows and migration was mainly from European countries.

We use a similar approach to derive an instrument for the size of the structural reform shock experienced by each community. As discussed earlier, the impact of the structural reform process varied a great deal across industries with manufacturing and agriculture strongly impacted by the opening of free trade and removal of subsidies. Hence, we use the industry distribution in different locations to predict the spatial distribution of the structural reforms.

Specifically, we calculate

$$
\operatorname{Inc} S h_{\jmath}=\sum_{n} \delta_{j n}^{86} \operatorname{IncSh}_{n}
$$

where $I n \hat{c} S h_{J}$ is the predicted income loss in location $j$ and is equal to the distribution of employment in 265 4-digit industries in each location $j$ in 1986 multiplied by the loss in income at the national level in each of these industries between 1986 and 1991 . We also treat nonemployment as an industry in order to capture the impact of the large changes in the welfare system that accompanied the reforms. The industry distribution in 1986 was primarily driven by long-term comparative advantage and the incentives of the pre-structural reform period, hence the distribution of shocks should be exogenous relative to prior economic and political outcomes.

To assess the validity of our instruments, in Table 3, we present results from regressions of the two instruments on voting in the 1984 election, which was prior to the start of the structural reform process and change in the immigration system. Here, we use official polling data at the area unit level and also include controls for AU characteristics. We find no relationship between either predicted migration flows or structural reform shocks and whether individuals voted in 1984 for the traditional parties of Labour and National as opposed to a precursor 
protest party called Social Credit, which received 7.6 percent of the vote in that election. The effect sizes for both variables are small and we fail to reject that they are jointly unrelated to voting patterns with a $p$-value greater than 0.70 .

Figure 3 plots predicted versus actual shocks across the 140 LMAs in 1996 with the size of each point reflecting the population of the LMA. Each graph also shows the fitted linear relationship between predicated and actual shocks where LMAs are weighted by their population. This is a graphical representation of the two first-stages of our regression model. ${ }^{16}$ A one percentage-point change in the predicted migration (structural reform) shock is correlated with a 0.95 (2.41) percentage-point change in the actual migration (structural reform) shock, which is significant at the 0.01 (0.001) percent level. This shows that both of our instruments have good predictive power. We discuss the first-stage regressions in more detail below.

\section{Results}

\subsection{Main Results}

In Table 4, we report results from estimating various specifications of regression model (1). The first four columns present the OLS results from 1993 and 1996 elections at ED level. Shocks are positively correlated with voting for NZF in both years, although only the coefficient for the immigration shock in the 1996 elections is (weakly) significant. If we instead estimate the model for 1996 using LMA level variation, but otherwise keep the same control variables, we find similar point estimates for our shock variables, and both are now statistically significant at the 5 percent level. Here, a one percentage-point increase in recent arrivals is associated with a 0.82 percentage-point increase in the share of votes for NZF and a one percentage-point increase in income loss is associated with a 0.53 percentage-point increase. Including additional controls for local area characteristics and electoral district fixed effects has a small impact on the point estimates, although now the impact of the immigration shock is no longer significant.

As discussed above, one might be concerned about the endogeneity of shocks, particularly in regard to the sorting of immigrants and natives across locations. The next four columns of Table 4 present the results for the same models but using the instrumental variables described above. Appendix Table 2 presents the two first-stage regressions corresponding to each of these

16 This is only true in a simplified sense because in the actual instrumental variables model both instruments are included as regressors in each first-stage along with all the other included control variables. 
specifications. As hinted at in Figure 3, the instruments are generally strong, particularly in our preferred specification that focuses on LMAs and controls for local area characteristics and ED fixed effects (here, the F-stat is 20.0 for the immigration shock and 38.7 for the structural reform shock, and the joint significance F-stat is 847). In each specification, we can rule out that the model is underidentified. While the estimates for 1993 are still imprecise, all specifications for 1996 find a significant effect of the immigration and structural reform shocks on voting for NZF.

In our preferred specification with the most complete set of controls, we find that a one percentage-point increase in recent arrivals causes a 4.78 percentage-point increase in the NZF vote share while a one percentage-point greater income loss causes a 1.32 percentage-point increase in vote share relative to a mean vote share of 10.7 percent for NZF. The increased size of the coefficients with respect to the OLS estimates likely indicates that immigrants do indeed avoid moving to locations that are receptive to populist voting and that individuals most negatively impacted by economic reforms and likely to vote for NZF are more likely to have moved away from impacted locations.

In Figure 4, we illustrate the size of these impacts by predicting the vote share for NZF in 1996 across the quantile distribution of each shock variable, holding all other variables constant. This is done using the preferred IV specification with the most complete set of controls. In LMAs where recent arrivals are in the first quartile, NZF is predicted to get slightly more than 4 percent of the votes, while if the arrivals are in the highest quartile, the votes share for NZF would instead be 25.8 percent. For the structural reform shock, the vote share for NZF increases from 5.7 percent in LMAs in the first quartile of the structural reform shock distribution to 19.8 percent in the highest quartile. It is clear from this figure that the size of the shocks experienced by an individual are important for explaining whether they voted for NZF in 1996.

In column 9 of Table 4, we examine whether the source of recent immigration matters. We do this by splitting the immigration shock variable into additive "Asian" and "Non-Asian" components. Recalling that most Asian immigration is new to NZ since the change in the immigration system, our instrument for Asian immigration is unsurprisingly weaker than for non-Asian immigration. However, we find a large statistically significant impact of Asian immigration and a negative but very imprecisely estimated impact of non-Asian immigration. While we need more precision to say anything definitive here, there is strong suggestive evidence that the changing composition of migration to NZ was an important component leading to the development of NZF. We also examined whether there was an interaction 
between the immigration and structural reform shock and, perhaps surprisingly, found the impacts are essentially orthogonal.

In our final specification, we add controls for a wide range of political opinions, beliefs, and policy preferences. Specifically, we include variables for own ideological position, own opinion on the position of NZF, trust in the Labour and National parties, mistrust toward mainstream parties, opinions about main party leaders, opinions about the country's financial situation, immigration, taxes, redistribution and social conservatism, and previous voting in 1990. The variables are clearly along the causal chain when evaluating the impact of the shocks on voting for NZF; we also consider them as outcomes in later analysis. Including them here allows us to estimate how much of the effect of shocks on voting for NZF occurs via changes in these characteristics. The estimated coefficients on both shock variables decrease in this specification by $29 \%$, so nearly one-third of the impact of shocks on voting for NZF occurs because of the impact of these shocks on political opinions, beliefs, and policy preferences.

In Table 5, we use our preferred IV specification to estimate the impact of shocks on voting for other political parties and whether people vote. ${ }^{17} \mathrm{We}$ do not find any significant impact of the shocks on the other political parties or turnout. Votes for Labour move in the same direction as those for NZF, while votes for National and Alliance move in the opposite direction, but all point estimates have very high standard errors compared with the size of the coefficients. Labour and National could well have been considered by the electorate as responsible for the effect of the reforms that followed the economic crisis and for opening up NZ to new migration in the same respect, but Alliance was never in government and was a left-wing party whose policy platform focused on mitigating the impact of the economic shocks causes by the structural reform process. Hence, the results here are consistent with shocks pushing people towards populism as opposed to towards parties with particular policy platforms.

\subsection{Impact on Beliefs and Political Preferences}

In this section, we examine the impact of shocks on beliefs and political preferences. We do this to better understand how the impact of the shocks translated into the emergence of populism. We estimate the same model as in the previous section focusing on the instrumental variable specification that includes controls for area characteristics as well as ED fixed effects,

17 Guiso et al. (2017) finds that populist parties impact turnout in Europe and that this is an important component of how they gain votes. 
but now we examine the impact on a wide range of outcome variables that measure beliefs and political preferences in 1996.

Table 6 presents the results of this analysis: each line corresponds to a separate regression run for a different dependent variable with only the coefficients on the shock variables and their associated standard errors presented in the columns next to them. Shocks do not impact own left/right ideology or an index of self-reported social conservatism. On the other hand, we find impacts on particular policy preferences with the two shocks working through quite distinct channels. Experiencing a larger immigration shock causes individuals to report themselves as being more hostile to immigration and that defense and law and order should be more important policy areas. Experiencing a larger income loss from structural reforms causes individuals to report themselves as being more in favor of redistribution, that they believe recent policies were bad for the country, and that unemployment should be a larger and economic growth a smaller policy concern. ${ }^{18}$ In both cases, the results are consistent with how one would imagine these particular shocks impacting individuals.

We next examine whether shocks impacted populist beliefs, in particular whether people believe that a strong leader is needed and if they mistrust both traditional political parties. Here, we assign the value 1 if the subject trusts neither the Labour nor the National party and 0 if they trust both parties. When they express a positive judgment only on one of them, the variable is coded as 0.5 . A majority of individuals (50\%) aspires for a strong leader, while only $27 \%$ are against a strong leader, and $15 \%$ of individuals mistrust both traditional parties in comparison to $10 \%$ who trust both. We find that experiencing a larger size of either shock causes people to think that a strong leader is needed and increases their mistrust of traditional parties. The magnitudes of the effects are similar in size to the impacts that the shocks have on voting for NZF.

A strand of the political science literature emphasizes the role of leaders in explaining the emergence of populism (Weyland 2001; Laclau 2005). For this reason, we also test whether experiencing shocks affects how individuals feel about the leaders of the main political parties, namely Winston Peters for NZF, Jim Bolger for National, and Helen Clark for Labour. These variables are coded as 1 if an individual says they trust the specific politician. We find some

18 These variables are generally yes/no questions where individuals can also choose "indifferent or undecided". We code these variables as 0 for no, 1 for yes and 0.5 for neither yes nor no. The results are generally insensitive to instead dropping undecided people. We have included here the full set of policy areas that individuals were asked about in the survey. 
weak evidence that individuals who experience a larger structural reform shock are more trusting of Peters, but more generally feelings for leaders appear to be a noisier mediator than the other opinions.

To sum up, shocks not only impact populist voting but also individual beliefs and political preferences, in particular the desire for a strong leader and mistrust toward both mainstream parties. As discussed above, the impact of shocks on these variables explains around 30 percent of the overall impact of shocks on voting for NZF, hence changing beliefs and preferences are an important part of the story of how NZF initially developed.

\subsection{Demand for and Supply of Political Change}

One important but difficult question to answer is whether the shocks experienced in NZ led to increased support for populism via the 'demand' pathway highlighted in the previous section and/or by changing the 'supply' of populism via the creation of NZF (Guiso et al. 2017). In the previous section, we showed that shocks led to increased populist attitudes, in particular the desire for a strong leader and mistrust toward both mainstream parties hinting towards the importance of a demand channel. In Table 7, we examine whether there is a relationship between experiencing either shock and voting for changing the political system to MMP in the binding referendum that was held in 1993, as reported by individuals in the 1993 NZES. As discussed in Riambau et al. (2021), individuals who desired political change and supported minority parties strongly supported the change to MMP. Consistent with experiencing shocks leading to increased demand for political change, we find a strong significant impact of having experienced an immigration shock on individual's voting for changing the political system.

Examining the impact of shocks on the supply of 'populism' is more difficult. One thing we can examine is whether NZF was more likely to field candidates in electorates in 1993 that experienced larger shocks (they fielded a candidate in 84 out of 99 electorates). We also show these results in Table 7 using the same regression framework as in the previous analyses so that the results reflect outcomes for the average NZer, not the average electoral district. We do not find a significant relationship between either shock and the supply of populism measured on this dimension. While the standard errors are large, the point estimates suggest that NZF was actually less likely to field candidates in electoral districts that experienced larger shocks.

\subsection{Persistence of the Impact of the Shocks}

We next examine if the impact of the shocks on voting for NZF persists over time. We continue to estimate our preferred specification from Table 4 but now examine voting for NZF in the 
next six elections, from 1999 to 2014. Turning to Table 8, we can see that the shocks have persistent impacts on voting for NZF. In 1999, the impacts are about half the size as in 1996 but significant for both shocks. Shocks then appear be become less important over time, until the 2014 election, when the immigration shock (experienced in a LMA between 1991 and 1996) again has a large impact on voting for NZF. Pooling all six elections together and including election fixed effects, we find similar long-run impacts of both shocks, but only the impact of the structural reform shock is statistically significant.

There is some evidence that populist parties thrive when they are in opposition but do not perform so well once they are in power (Heinisch 2010). On the relationship between populists' performance and the economic outlook, there is mixed evidence: at the individual level, research suggests there is a relationship between votes for populist parties and economic insecurity (Guiso et al. 2017), while macro evidence does not support this (Boeri et al. 2018). In our final specification, we examine whether macro political or economic factors are related to the observed variation over time in the impact of the shocks on voting for NZF. Specifically, we interact whether NZF is in opposition at the time of the election and the change in the unemployment rate since the last election with both shock variables in a regression that pools all elections since 1999 and includes election fixed effects.

We find that both shocks are important for explaining voting for NZF whenever they are in opposition (and generally that voting is higher for NZF when they are in opposition). There is also some evidence that the structural reform shock has a larger impact when the economy is improving (which is also correlated with NZF doing better). We suspect that the latter occurs because NZF does not focus on economic policy and the rhetoric around immigration in NZ is more about the negative impact of inflows on house prices and local amenities rather than on labor markets and hence tends to be more in focus when the economy is doing well (Vowles and Curtin 2020). Overall, the shocks seem to have some long-term memory in them. They wound an area, and this comes to the surface whenever particular conditions are realized.

\subsection{Heterogeneity Analysis}

We next examine heterogeneity in impact of shocks in order to better understand the potential channels behind our findings. Populism is a complex phenomenon characterized over a wide range of economic, sociological, and psychological angles, so we investigate several transmission mechanisms without a definite theoretical structure. We examine two potential mechanisms. First, we examine how the impact of the shocks varies by individual and 
community characteristics. Given that these characteristics are exogenous to the shocks, we are able to identify how the causal impact of each shock varies across individuals and communities with different characteristics. Then, we examine how the shocks interact with political preferences and beliefs. This analysis is only suggestive as we have already shown that shocks directly influence preferences and beliefs.

Table 9 presents the results from our individual heterogeneity analysis. In each column, we consider a different dimension of potential variation. In each case, we interact a dummy variable for the noted category with each of the shock variables and also include it as a control if it is not already included. ${ }^{19}$ These models are again estimated using instrumental variables, with instruments for the interactions as well, and include controls for local characteristics and ED fixed effects. For example, in the first column we report results where a dummy variable for being under age 35 is interacted with the shock variables.

In general, we find little evidence of heterogenous impacts of shocks across individual characteristics. The only exceptions are that we find that structural reform shocks have larger effects on voting for NZF for older individuals and individuals who are not employed. NZF has a strong focus on improving policies for older individuals, such as free use of health services and public transit, and keeping the retirement age from increasing, which may explain these results. The overall lack of heterogenous impacts in relationship to individual, as opposed to community characteristics as discussed next, occurs even though the economic shock clearly had large negative impacts on low skill, poor, and less educated individuals, and high-skilled migrants are most likely to compete in the labor market with more educated higher-skilled workers. Taken together, this evidence suggests that standard economic explanations for populism are not what drove the emergence of NZF.

In our final two specifications, we examine the role of community characteristics. Specifically, we examine whether the shocks have differential impacts in areas with a long-run history of immigration and in urban versus rural areas. ${ }^{20}$ Consistent with previous research (Dustmann et

19 Low skilled workers are those not in groups 1 (managers), 2 (high-level professionals), or 3 (low-level professionals) based on self-reported occupation. High income is defined as being above the median. Benefits include unemployment benefits, support for sickness and domestic purposes benefits to single parent families. Eligibility for these benefits was greatly reduced between 1991 and 1993, for example in our sample the number of people receiving benefits declined from $41 \%$ in 1990 to $16 \%$ in 1996 . We use the 1990 NZES to examine the relationship between benefit receipt and individual characteristics and then predict who receives benefits in 1996 holding all else constant. We do not find an impact of losing benefit eligibility on voting for NZF.

20 High density areas have a population density greater than 50 people per square $\mathrm{km}$. This splits the sample in a balanced way, while only 26 LMAs out of 141 are classified as high density they have an average 56 thousand 
al. 2019, Levi et al. 2020), we find that in high density areas neither immigration nor structural reform shocks impact voting for NZF. The impact of shocks is fully concentrated in lower density LMAs. This may occur because the distinction between rural areas and urban areas carries forward long-lasting political preferences and different ways of organizing political life (Cramer 2016) or because people in more densely populated regions are exposed to cosmopolitan beliefs. We also find that the impact of the immigration shocks on voting for NZF is much higher in areas that historically had less immigration and that there is no impact in areas that already had high levels of immigration in 1986. This is consistent with the cultural channel being particularly important for understanding how immigration shocks lead to populist voting.

In Table 10, we present the results of a further heterogeneity analysis where we examine whether the impact of shocks varies by political preferences and beliefs. ${ }^{21}$ Here, we present results from models that measure political preferences and beliefs contemporaneously with voting. As we have shown in Table 5, shocks impact these variables, hence they are clearly along the causal chain and cannot be interpreted as providing causal estimates of interaction effects. However, they can still provide suggestive evidence on which transmission mechanisms are important and help discriminate between different potential explanations of the shocks' impact on populism.

A number of patterns stand out. First, the immigration shock had strong impacts on voting for NZF for individuals with a wide variety of opinions and beliefs. Second, this is generally true for the structural reform shock as well, but here there is more heterogeneity. In particular, incomes losses from structural reforms are more strongly related to voting for NZF among individuals who are left-wing, hostile to immigration, in favor of redistribution, think that recent policies are bad for the country, have mistrust towards mainstream parties and have more positive feelings about Winston Peters. This suggests that the large income shock caused by structural reforms at the end of the 1980s translated into the emergence of NZF through both its impact on and interaction with anti-immigration, pro-redistribution, and anti-elite attitudes.

inhabitants compared with 11 thousand in the low density LMAs. High immigration areas are defined as areas where the immigration share was above the mean level.

$21 \mathrm{We}$ attempted to do this analysis exploiting the longitudinal component of the NZES to measure these variables in 1990 before the emergence of NZF, but we did not have enough precision to say anything meaningful. 


\subsection{Relative Importance of Shocks}

Up to now, we have focused on the role of the two shocks experienced by NZers in the early 1990s. We have shown that these shocks impacted political party preferences and opinions and encouraged the emergence of populism. Our analysis has also shown that cultural aspects appear to be important for understanding the impact of these shocks, particularly the immigration shock. Political scientists argue that economic factors are unlikely to be main drivers of populism (Oesch, 2008, Norris and Inglehart, 2019). To contribute to this literature, in our final analysis, we now compare the explanatory power of different factors related to voting for NZF in order to demonstrate the relative importance of the two shocks we examine vis a vis other factors that might explain the overall variability in voting for NZF.

In Figure 5, we graph the partial R-squared (squared partial correlation) for different groups of variables as estimated in our preferred regression model, as well as in the extended specification that includes controls for political preferences, beliefs, and opinions. This is the proportion of the variation in voting for NZF that is left unexplained by other predictors $\left(x_{2}\right)$ in the model but is explained by a particular group $\left(x_{1}\right) .{ }^{22}$ This provides a ranking of the explanatory power of different groups of non-overlapping variables. The dotted lines are at 0.17, the overall R-squared for the first model, and 0.36 , the overall R-squared for the second model.

In our main model, variation in shocks explains a bit more than 10 percent of the overall variation in voting for NZF, slightly less than the combined effect of various individual demographic, social, and economics characteristics. However, in our extended model, it is clear that differences in preferences, beliefs, and opinions are even more important for explaining the variation in populist voting. Variation in these variables accounts for 30 percent of the overall variation in voting for NZF. However, it is important to remember that experiencing shocks also impacts these variables, which is why additively the total variation explained by shocks in addition to that by and preferences, beliefs, and opinions is greater than the model $\mathrm{R}$-squared. Taken together, these results show that there is an important role for both structural reform and immigration shocks in explaining the rise of populism in NZ, and that the impact of these shocks both amplifies and is amplified by differences in political beliefs and opinions.

22 The partial R-squared of a group of variables, $x_{l}$, is calculated as the reduction in the overall R-squared of the model when these variables are excluded relative to the proportion of the variance that is left unexplained in the model that only includes $x_{2}$ as controls (in other words, $1-\mathrm{R}$-squared $\left(x_{2}\right)$ ). This partials out both the influence of $x_{2}$ on the outcome variable and the influence of $x_{2}$ on $x_{1}$. 


\section{Conclusions}

In this paper, we use electoral survey data to examine the impact that two large external shocks had on the development of New Zealand First, one of the oldest populist parties in the OECD. We examine the impact of structural reforms that led to large negative impacts on particular industries and immigration reforms that led to large increases in skilled migration: i) on voting for New Zealand First in its first years of existence; ii) on individual beliefs and political preferences including the supply of and demand for political change; iii) on the long-run persistence in voting for New Zealand First; and iv) relative to other factors that encourage people to vote for New Zealand First;

We find that these shocks had large impacts on voting for New Zealand First in its initial years, that they also impacted preferences and beliefs, that they continue to influence voting even 30 years later. Overall, the occurrence of these shocks appears to be an important driver of demand for political change and the emergence of a strong populist party in New Zealand. Even though one of the shocks we examine is 'economic' and the second has a strong economic component, our evidence suggests that cultural and political channels are more important than economic ones for understanding how populism took hold in New Zealand.

New Zealand is in many ways a forerunner to many of the current trends affecting OECD countries. The structural reform process that occurred in the $1980 \mathrm{~s}$ increased competition for certain industries in a similar way that China joining the WTO impacted industries in the rest of the developed world in the 2000s. Similarly, New Zealand was one of the first countries to develop a skilled migration system that had no restrictions on country of origin. In this sense, it is unsurprising that populist parties are emerging in European countries that in recent years have featured increased competition in many economic sectors and a large inflow of ethnically diverse migrants, despite little experience receiving immigrants from locations other than former colonies. 


\section{Reference}

Ahlquist, John, Mark Copelovitch, and Stefanie Walter. 2020. "The political consequences of external economic shocks: evidence from Poland." American Journal of Political Science 64, no. 4: 904-920.

Akkerman, Agnes, Cas Mudde, and Andrej Zaslove. 2014. "How populist are the people? Measuring populist attitudes in voters." Comparative Political Studies 47, no. 9: 13241353.

Alabrese, Eleonora, Sascha O. Becker, Thiemo Fetzer, and Dennis Novy. 2019. "Who voted for Brexit? Individual and regional data combined." European Journal of Political Economy 56: 132-150.

Alesina, Alberto F., Davide Furceri, Jonathan D. Ostry, Chris Papageorgiou, and Dennis P. Quinn. 2020. "Structural reforms and elections: Evidence from a world-wide new dataset”. National Bureau of Economic Research Working Paper w26720.

Algan, Yann, Sergei Guriev, Elias Papaioannou, and Eugenia Passari. 2017. "The European trust crisis and the rise of populism." Brookings Papers on Economic Activity 2017, no. 2: 309-400.

Altonji, Joseph G., and David Card. 1991. "The effects of immigration on the labor market outcomes of less-skilled natives." In Immigration, Trade, and the Labor Market, 201234. University of Chicago Press.

Anelli, Massimo, Italo Colantone, and Piero Stanig. 2019. "We were the robots: Automation and voting behavior in western Europe." BAFFI CAREFIN Centre Research Paper 2019115.

Barone, Guglielmo, Alessio D'Ignazio, Guido De Blasio, and Paolo Naticchioni. 2016. "Mr. Rossi, Mr. Hu and politics. The role of immigration in shaping natives' voting behavior." Journal of Public Economics 136: 1-13.

Bartel, Ann P. 1989. "Where do the new US immigrants live?." Journal of Labor Economics 7, no. 4: 371-391.

Becker, Sascha O., Thiemo Fetzer, and Dennis Novy. 2017. "Who voted for Brexit? A comprehensive district-level analysis." Economic Policy 32, no. 92: 601-650.

Boeri, Tito, Prachi Mishra, Chris Papageorgiou, and Antonio Spilimbergo. 2018. "A Dialogue between a Populist and an Economist." In AEA Papers and Proceedings, vol. 108, pp. $191-95$. 
Boston, Jonathan, and Elizabeth McLeay. 1997. "Forming the first MMP government: theory, practice, prospects." In From Campaign to Coalition: New Zealand's First General Election Under Proportional Representation, edited by Boston, J., Levine, S., McLeay, E., \& Roberts, N.. Dunmore Press.

Boston, Jonathan, Paul Dalziel, and Susan St John, eds. 1999. Redesigning the Welfare State in New Zealand: Problems, Policies, Prospects. Auckland: Oxford University Press.

Burgoon, Brian, Sam van Noort, Matthijs Rooduijn, and Geoffrey Underhill. 2019. "Positional deprivation and support for radical right and radical left parties." Economic Policy 34, no. 97: 49-93.

Burke, Kerry. 1986. Review of Immigration Policy. Appendices to the Journal of the House of Representatives G42, Government Printer, Wellington.

Card, David, Christian Dustmann, and Ian Preston. 2012. "Immigration, wages, and compositional amenities." Journal of the European Economic Association 10, no. 1: 78119.

Colantone, Italo, and Piero Stanig. 2018. "Global competition and Brexit." American Political Science Review 112, no. 2: 201-218.

Colantone, Italo, and Piero Stanig. 2018b. "The trade origins of economic nationalism: Import competition and voting behavior in Western Europe." American Journal of Political Science 62, no. 4: 936-953.

Colantone, Italo, and Piero Stanig. 2019. "The surge of economic nationalism in Western Europe." Journal of Economic Perspectives 33, no. 4: 128-51.

Cramer, Katherine J. 2016. The Politics of Resentment: Rural Consciousness in Wisconsin and the Rise of Scott Walker. University of Chicago Press.

Dal Bó, Ernesto, Frederico Finan, Olle Folke, Torsten Persson, and Johanna Rickne. 2020. "Economic and Social Outsiders but Political Insiders: Sweden's Radical Right.". https://eml.berkeley.edu/ ffinan/Finan_SwedenDemocrats.pdf

Di Tella, Rafael, and Julio J. Rotemberg. 2018. "Populism and the return of the "paranoid style": Some evidence and a simple model of demand for incompetence as insurance against elite betrayal." Journal of Comparative Economics 46, no. 4: 988-1005.

Dippel, Christian, Robert Gold, Stephan Heblich, and Rodrigo Pinto. 2017. "Instrumental variables and causal mechanisms: Unpacking the effect of trade on workers and voters." National Bureau of Economic Research Working Paper No. w23209. 
Dorn, David, Gordon Hanson, and Kaveh Majlesi. 2020. "Importing political polarization? The electoral consequences of rising trade exposure." American Economic Review 110, no. 10: $3139-83$.

Dustmann, Christian, Kristine Vasiljeva, and Anna Piil Damm. 2019. "Refugee migration and electoral outcomes." The Review of Economic Studies 86, no. 5: 2035-2091.

Edo, Anthony, Yvonne Giesing, Jonathan Öztunc, and Panu Poutvaara. 2019. "Immigration and electoral support for the far-left and the far-right." European Economic Review 115: 99-143.

Eribon, Didier. Returning to Reims. Penguin UK, 2018.

Evans, Lewis, Arthur Grimes, Bryce Wilkinson, and David Teece. 1996. "Economic reform in New Zealand 1984-95: The pursuit of efficiency." Journal of Economic Literature 34, no. 4: 1856-1902.

Funke, Manuel, Moritz Schularick, and Christoph Trebesch. 2020. Populist Leaders and the Economy. CEPR Discussion Paper 15405.

Gest, Justin. 2016. The New Minority: White Working Class Politics in an Age of Immigration and Inequality. Oxford University Press.

Gibson, John K., and Richard ID Harris. 1996. "Trade liberalisation and plant exit in New Zealand manufacturing." The Review of Economics and Statistics: 521-529.

Guiso, Luigi, Helios Herrera, Massimo Morelli, and Tommaso Sonno. 2017. "Populism: Demand and Supply." CEPR Discussion Paper, No. DP11871.

Guiso, Luigi, Helios Herrera, Massimo Morelli, and Tommaso Sonno. 2019. "Global crises and populism: the role of Eurozone institutions." Economic Policy 34, no. 97: 95-139.

Guriev, Sergei, and Elias Papaioannou. 2020. "The political economy of populism." Journal of Economic Literature, forthcoming.

Hainmueller, Jens, and Daniel J. Hopkins. 2014. "Public attitudes toward immigration." Annual Review of Political Science 17: 225-249.

Halla, Martin, Alexander F. Wagner, and Josef Zweimüller. 2017. "Immigration and voting for the far right." Journal of the European Economic Association 15, no. 6: 1341-1385.

Heinisch, Reinhard. 2003. "Success in opposition-failure in government: explaining the performance of right-wing populist parties in public office." West European Politics 26, no. 3: 91-130.

Hochschild, Arlie Russell. 2016. "The ecstatic edge of politics: Sociology and Donald Trump." Contemporary Sociology 45, no. 6: 683-689. 
Im, Zhen Jie, Nonna Mayer, Bruno Palier, and Jan Rovny. 2019. "The "losers of automation": A reservoir of votes for the radical right?." Research \& Politics 6, no. 1: 2053168018822395.

Jaeger, David A., Joakim Ruist, and Jan Stuhler. 2018. "Shift-share instruments and the impact of immigration.” National Bureau of Economic Research Working Paper No. w24285.

Laclau, Ernesto. On populist reason. Verso, 2005.

Levi, Eugenio, Rama Dasi Mariani, and Fabrizio Patriarca. 2020. "Hate at first sight? Dynamic aspects of the electoral impact of migration: the case of Ukip." Journal of Population Economics 33, no. 1: 1-32.

Maré, David C., Melanie Morten, and Steven Stillman. 2007. "Settlement patterns and the geographic mobility of recent migrants to New Zealand." New Zealand Economic Papers 41, no. 2: 163-195.

Margalit, Yotam. 2019. "Economic insecurity and the causes of populism, reconsidered." Journal of Economic Perspectives 33, no. 4: 152-70.

McMillan, John. 1998. "Managing Economic Change: Lessons from New Zealand." World Economy 21, no. 6: 827-843.

Moffitt, Benjamin. 2016. The Global Rise of Populism: Performance, Political Style, and Representation. Stanford University Press.

Moriconi, Simone, Giovanni Peri, and Riccardo Turati. 2019. "Immigration and voting for redistribution: Evidence from European elections." Labour Economics 61: 101765.

Mudde, Cass. 2007. Populist Radical Right Parties in Europe (Vol. 22, No. 8). Cambridge: Cambridge University Press.

Mudde, Cass. 2019. The Far Right Today. John Wiley \& Sons.

Norris, Pippa, and Ronald Inglehart. 2019. Cultural Backlash: Trump, Brexit, and Authoritarian Populism. Cambridge: Cambridge University Press.

Oesch, Daniel. 2008. "Explaining workers' support for right-wing populist parties in Western Europe: Evidence from Austria, Belgium, France, Norway, and Switzerland." International Political Science Review 29, no. 3: 349-373.

Papps, Kerry L., and James O. Newell. 2002. "Identifying functional labor market areas in New Zealand: A reconnaissance study using travel-to-work data." IZA Discussion Paper 443.

Riambau, Guillem, Steven Stillman, and Geua Boe-Gibson. 2021. "What determines preferences for an electoral system? Evidence from a binding referendum." Public Choice 186, no. 1: 179-208. 
Rodrik, Dani. 2018. "Populism and the economics of globalization." Journal of International Business Policy 1, no. 1: 12-33.

Spruyt, Bram, Gil Keppens, and Filip Van Droogenbroeck. 2016. "Who supports populism and what attracts people to it?." Political Research Quarterly 69, no. 2: 335-346.

Stillman, Steven, Malathi Velamuri, and Andrew Aitken. 2010. "The long-run impact of New Zealand's structural reform on local communities." Journal of Comparative Economics 38, no. 4: 432-448.

Vowles, Jack, and Jennifer Curtin. 2020. A Populist Exception?: The 2017 New Zealand General Election. ANU Press.

Weyland, Kurt. 2001. "Clarifying a contested concept: Populism in the study of Latin American politics." Comparative Politics: 1-22. 
Figure 1: Evolution of Voting for New Zealand First

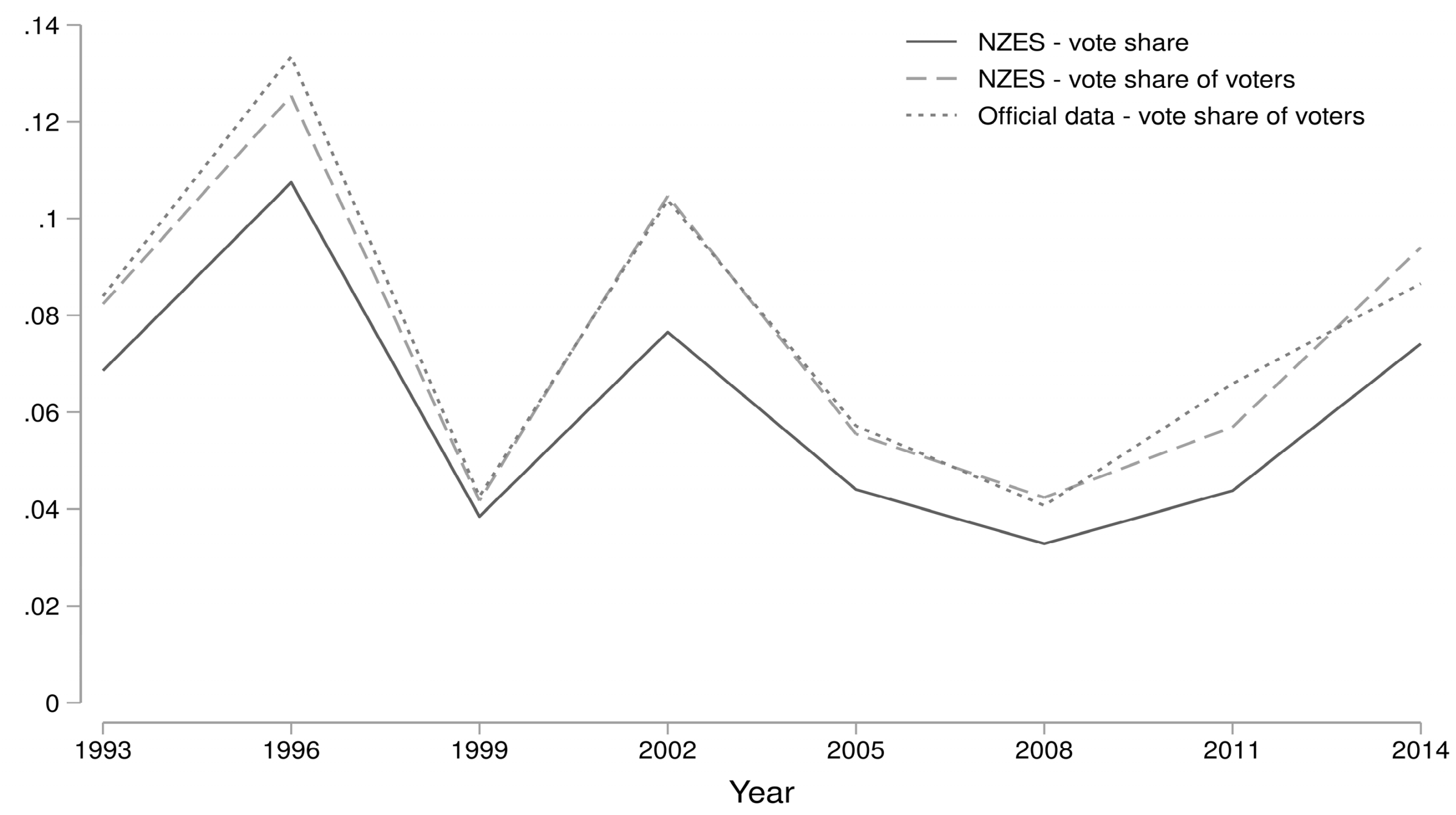


Figure 2. Spatial Distribution of Immigration and Structural Reform Shocks and Votes for New Zealand Firs1

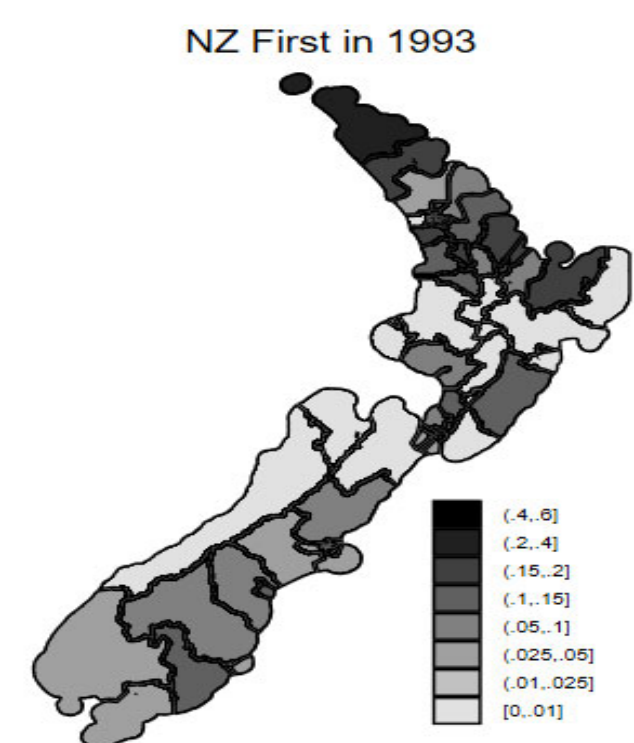

5-years Immigrant Arrivals in 1996

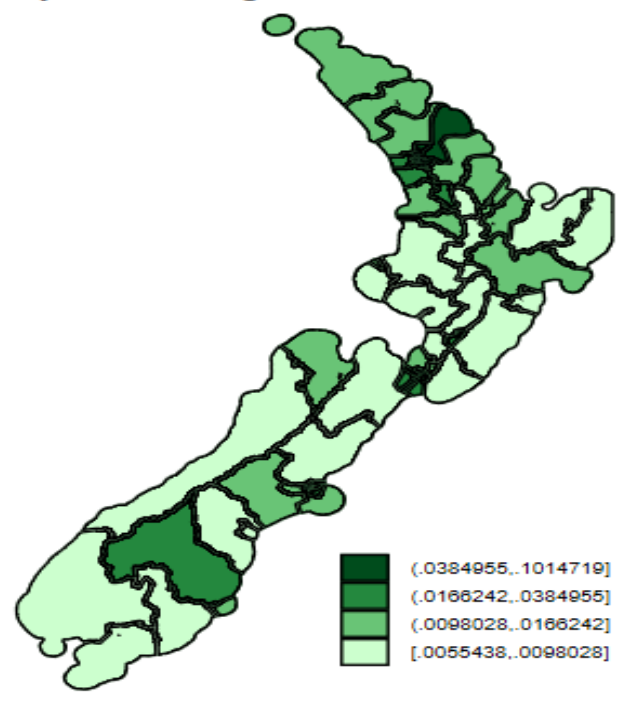

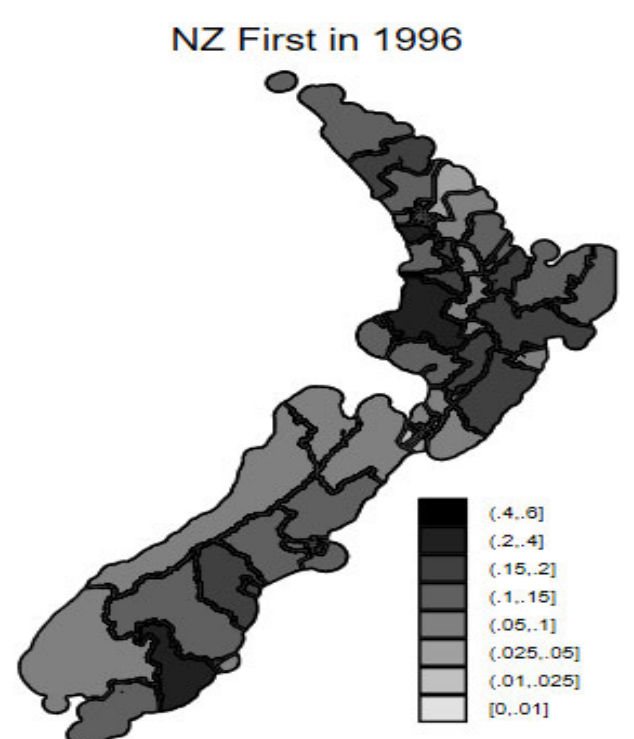

Percent Change in Income between 1986 and 1991

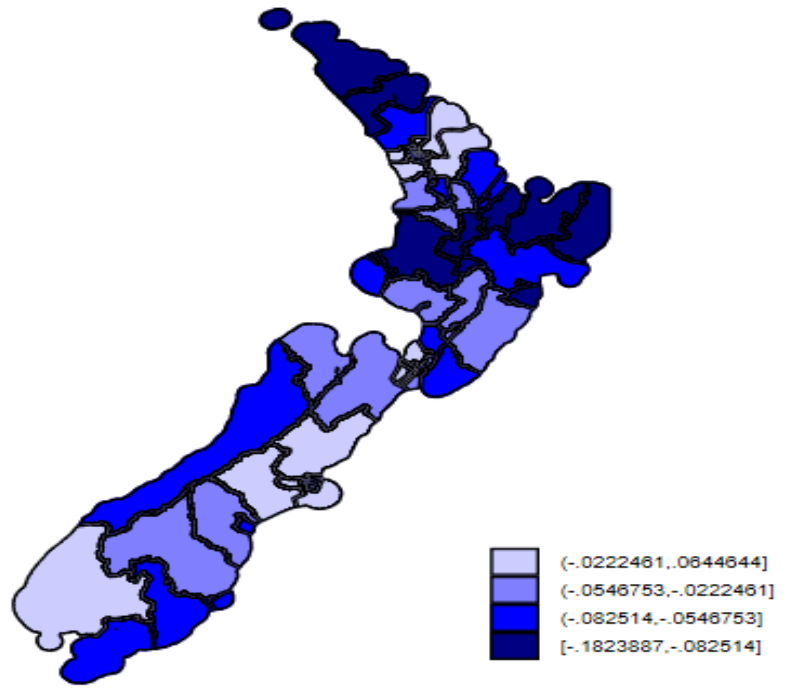


Figure 3. Scatter Plots of Predicted and Actual Shocks Across Labor Market Areas in 1996
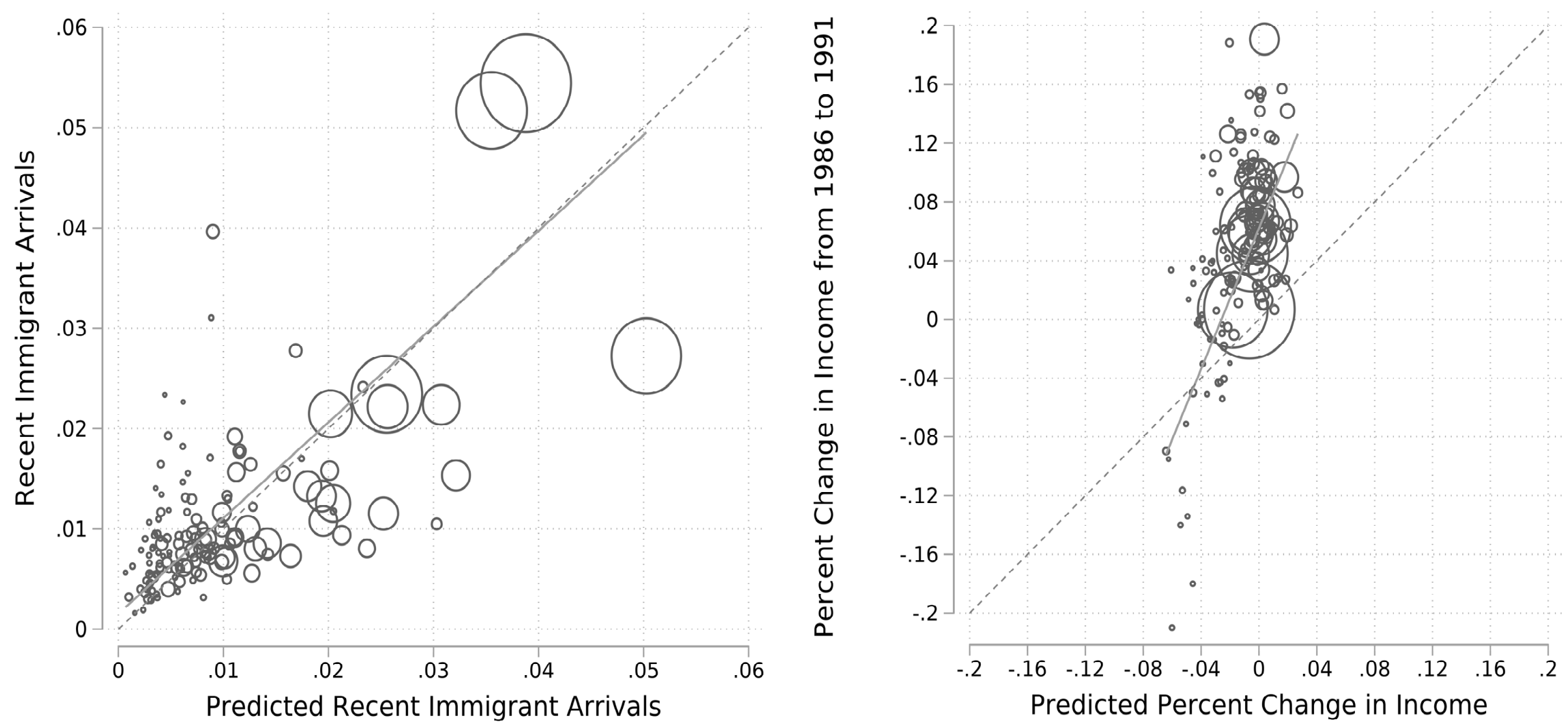
Figure 4: Predicted Impact of Shocks on Voting for New Zealand First in 1996
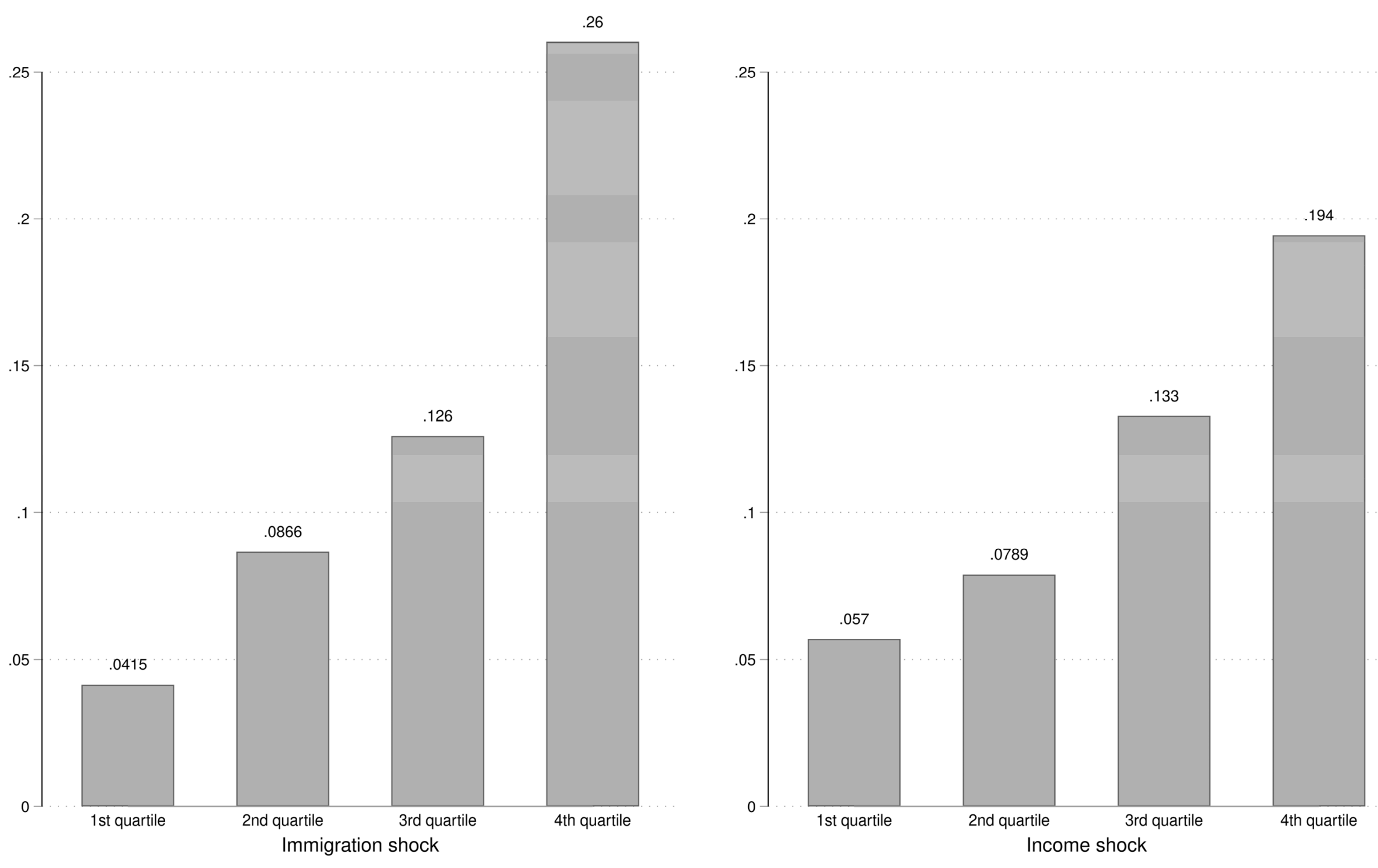
Figure 5. A Partial R-Squared Analysis of What Explains Voting for New Zealand First in 1996

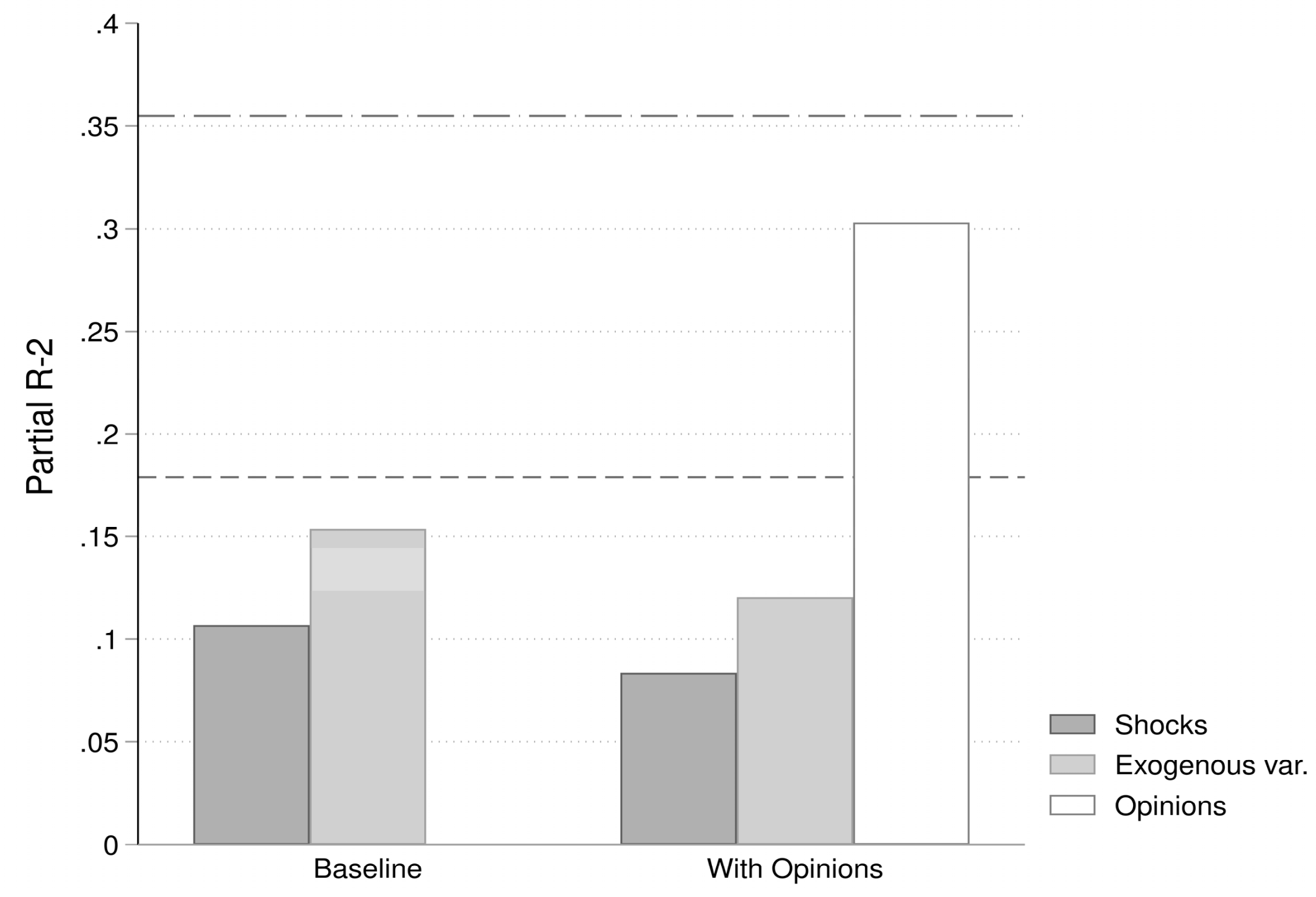


Table 1: Who Voted for New Zealand First in 1993 and 1996?

A) Among Those Who Voted for NZF in B) Among Those Who Voted for Party X 1993/96, Share Who Voted for Party X in 1990, Share Who Voted for NZF in in 1990 1993/96

\begin{tabular}{lllll}
\hline & 1993 & 1996 & 1993 & 1996 \\
\hline National Party & 0.544 & 0.358 & 0.092 & 0.121 \\
Labour Party & 0.181 & 0.278 & 0.042 & 0.105 \\
Alliance & 0.094 & 0.041 & 0.097 & 0.119 \\
Social Credit & 0.041 & 0.044 & 0.122 & 0.150 \\
Other Parties & 0.006 & 0.015 & 0.025 & 0.216 \\
Did Not Vote & 0.041 & 0.050 & 0.038 & 0.107 \\
Ineligible or Missing & 0.094 & 0.213 & 0.055 & 0.091 \\
\hline
\end{tabular}

Note: Results are weighted. Panel A shows voting in 1990 for people that voted for New Zealand First in either 1993 or 1996. Panel B shows the share that voted for New Zealand First in 1993 and 1996 among voters for different parties in 1990. 
Table 2: Summary Statistics for 1993 and 1996

\begin{tabular}{|c|c|c|c|c|c|c|c|c|}
\hline & \multicolumn{4}{|c|}{1993} & \multicolumn{4}{|c|}{1996} \\
\hline & \multicolumn{2}{|c|}{ Full Sample } & \multicolumn{2}{|c|}{ Analysis Sample } & \multicolumn{2}{|c|}{ Full Sample } & \multicolumn{2}{|c|}{ Analysis Sample } \\
\hline & Mean & $\mathrm{SD}$ & Mean & SD & Mean & $\mathrm{SD}$ & Mean & SD \\
\hline \multicolumn{9}{|l|}{ Voted for: } \\
\hline NZ First & 0.069 & 0.253 & 0.068 & 0.252 & 0.110 & 0.312 & 0.107 & 0.310 \\
\hline Labour & 0.281 & 0.450 & 0.281 & 0.449 & 0.248 & 0.432 & 0.255 & 0.436 \\
\hline National & 0.287 & 0.452 & 0.288 & 0.453 & 0.279 & 0.449 & 0.274 & 0.446 \\
\hline Far Left & 0.148 & 0.355 & 0.149 & 0.356 & 0.094 & 0.292 & 0.097 & 0.296 \\
\hline No vote & 0.167 & 0.373 & 0.167 & 0.373 & 0.127 & 0.333 & 0.123 & 0.328 \\
\hline \multicolumn{9}{|l|}{ Shocks: } \\
\hline Immigration Shock & 0.027 & 0.023 & 0.027 & 0.023 & 0.026 & 0.017 & 0.026 & 0.017 \\
\hline Asian Immig. Shock & & & & & 0.012 & 0.011 & 0.012 & 0.011 \\
\hline Non-Asian Immig. Shock & & & & & 0.014 & 0.007 & 0.014 & 0.007 \\
\hline Structural Reform Shock & 0.051 & 0.045 & 0.051 & 0.045 & 0.049 & 0.042 & 0.049 & 0.042 \\
\hline \multicolumn{9}{|c|}{ Individual Characteristics: } \\
\hline Female & 0.505 & 0.500 & 0.506 & 0.500 & 0.524 & 0.500 & 0.527 & 0.499 \\
\hline Under 35 & 0.294 & 0.456 & 0.295 & 0.456 & 0.334 & 0.472 & 0.337 & 0.473 \\
\hline Over 65 & 0.188 & 0.391 & 0.189 & 0.391 & 0.172 & 0.377 & 0.169 & 0.375 \\
\hline Maori & 0.063 & 0.242 & 0.063 & 0.243 & 0.081 & 0.273 & 0.085 & 0.279 \\
\hline European & 0.847 & 0.360 & 0.848 & 0.359 & 0.869 & 0.337 & 0.870 & 0.337 \\
\hline Pacific & 0.016 & 0.124 & 0.016 & 0.125 & 0.013 & 0.113 & 0.013 & 0.113 \\
\hline Other ethnicity & 0.032 & 0.175 & 0.032 & 0.176 & 0.027 & 0.163 & 0.027 & 0.162 \\
\hline Immigrant & 0.162 & 0.369 & 0.164 & 0.370 & 0.168 & 0.374 & 0.175 & 0.380 \\
\hline School Qualifications & 0.383 & 0.486 & 0.383 & 0.486 & 0.499 & 0.500 & 0.500 & 0.500 \\
\hline Post-School Quals & 0.189 & 0.391 & 0.189 & 0.392 & 0.302 & 0.459 & 0.308 & 0.462 \\
\hline University Degree & 0.101 & 0.302 & 0.101 & 0.302 & 0.108 & 0.311 & 0.109 & 0.312 \\
\hline Employed & 0.554 & 0.497 & 0.556 & 0.497 & 0.619 & 0.486 & 0.625 & 0.484 \\
\hline Unemployed & 0.046 & 0.210 & 0.046 & 0.210 & 0.031 & 0.172 & 0.030 & 0.171 \\
\hline NILF & 0.377 & 0.485 & 0.376 & 0.485 & 0.328 & 0.469 & 0.327 & 0.469 \\
\hline Household Income & 72430 & 41098 & 72,543 & 41,155 & 83,119 & 33,889 & 83,069 & 34,106 \\
\hline Religious & 0.192 & 0.394 & 0.192 & 0.394 & 0.174 & 0.379 & 0.171 & 0.376 \\
\hline Big Cities & 0.405 & 0.491 & 0.404 & 0.491 & 0.433 & 0.496 & 0.437 & 0.496 \\
\hline Other Cities & 0.269 & 0.443 & 0.270 & 0.444 & 0.239 & 0.427 & 0.243 & 0.429 \\
\hline Towns & 0.106 & 0.308 & 0.107 & 0.309 & 0.182 & 0.386 & 0.182 & 0.386 \\
\hline Rural & 0.206 & 0.405 & 0.208 & 0.406 & 0.122 & 0.328 & 0.115 & 0.319 \\
\hline \multicolumn{9}{|l|}{ Area unit characteristics: } \\
\hline Female & & & & & 0.519 & 0.028 & 0.519 & 0.025 \\
\hline Under 35 & & & & & 0.456 & 0.093 & 0.457 & 0.091 \\
\hline Over 65 & & & & & 0.169 & 0.072 & 0.169 & 0.072 \\
\hline Maori & & & & & 0.060 & 0.074 & 0.060 & 0.074 \\
\hline School Quals & & & & & 0.252 & 0.046 & 0.252 & 0.045 \\
\hline Post-school Quals & & & & & 0.190 & 0.041 & 0.190 & 0.041 \\
\hline University Degree & & & & & 0.087 & 0.075 & 0.087 & 0.075 \\
\hline Employment rate & & & & & 0.600 & 0.098 & 0.600 & 0.095 \\
\hline Unemployment rate & & & & & 0.072 & 0.040 & 0.071 & 0.040 \\
\hline Individual Income & & & & & 31,320 & 7,973 & 31,400 & 7,854 \\
\hline Gini index & & & & & 0.403 & 0.041 & 0.403 & 0.037 \\
\hline Population & & & & & 2,304 & 998 & 2,312 & 994 \\
\hline Observations & \multicolumn{2}{|c|}{2,232} & \multicolumn{2}{|c|}{2,211} & \multicolumn{2}{|c|}{4,113} & \multicolumn{2}{|c|}{3,473} \\
\hline
\end{tabular}

Means and standard deviations are presented. Results are weighted to reflect the average New Zealander age 18 and above. The immigration shock variables are defined as the number of recent arrivals relative to the total population in an area and the Asian and Non-Asian shock are additive. The income shocks is defined as the percent decline in income between 1986 and 1991 in an area. 
Table 3: The Relationship Between Shock Instruments and Official Voting in 1984

\begin{tabular}{lcc}
\hline & Labour and National & Social Credit \\
\hline Predicted Immigration Shock 1986 to 1991 & -0.129 & -0.336 \\
& $(0.340)$ & $(0.423)$ \\
Predicted Structural Reform Shock 1986 to 19! & -0.280 & 0.158 \\
& $(0.478)$ & $0.542)$ \\
& 0.722 & 0.752 \\
P-value for Test of Joint Signifiance & 0.786 & 0.076 \\
\hline Vote Share & 0.181 & 0.075 \\
\hline R-squared & 1,419 & 1,419 \\
Area Units & $* * *$ p $<0.01, * *$ p $<0.05, *$ p $<0.1$ Official voting data at the area unit level is used in these regresisons. Robust \\
standard errors in parentheses which allow for clustering at the LMA level. The two instruments are described in \\
the paper. All regressions also include controls for the following area unit characteristics: (log) population, \\
employment rate, unemployment rate, (log) mean income, gini index, and the proportion with school \\
qualifications, vocational qualifications and university degrees, under 35 and over 65, female and Maori.
\end{tabular}


Table 4: Impact of Shocks on Voting for NZ First in 1993 and 1996

\begin{tabular}{|c|c|c|c|c|c|c|c|c|c|c|}
\hline \multirow[b]{2}{*}{ Year } & \multicolumn{4}{|c|}{ OLS } & \multicolumn{6}{|c|}{ IV for Shocks Using Shift-Share Instruments } \\
\hline & 1993 & 1996 & 1996 & 1996 & 1993 & 1996 & 1996 & 1996 & 1996 & 1996 \\
\hline Shocks Measured at: & ED & ED & LMA & LMA & ED & ED & LMA & LMA & LMA & LMA \\
\hline Immigration Shock (\% Recent Arrivals) & $\begin{array}{c}0.904 \\
(0.602)\end{array}$ & $\begin{array}{c}0.617^{*} \\
(0.338)\end{array}$ & $\begin{array}{c}0.823 * * \\
(0.407)\end{array}$ & $\begin{array}{c}1.222 \\
(0.751)\end{array}$ & $\begin{array}{c}0.563 \\
(0.596)\end{array}$ & $\begin{array}{c}1.255^{*} \\
(0.651)\end{array}$ & $\begin{array}{c}1.881 * * * \\
(0.702)\end{array}$ & $\begin{array}{c}4.779 * * * \\
(1.526)\end{array}$ & & $\begin{array}{c}3.391 * * * \\
(1.226)\end{array}$ \\
\hline Structural Reform Shock $(\% \Delta 1986$ to 199 & $\begin{array}{c}0.183 \\
(0.165)\end{array}$ & $\begin{array}{c}0.127 \\
(0.116)\end{array}$ & $\begin{array}{c}0.530 * * * \\
(0.121)\end{array}$ & $\begin{array}{c}0.470 * * * \\
(0.178)\end{array}$ & $\begin{array}{c}0.383 \\
(0.371)\end{array}$ & $\begin{array}{c}0.519 * * \\
(0.262)\end{array}$ & $\begin{array}{c}0.933 * * * \\
(0.217)\end{array}$ & $\begin{array}{c}1.321 * * * \\
(0.338)\end{array}$ & $\begin{array}{c}1.109 * * \\
(0.452)\end{array}$ & $\begin{array}{c}0.935^{* * *} \\
(0.307)\end{array}$ \\
\hline $\begin{array}{l}\text { Asian Imm. Shock (\% Recent Arrivals) } \\
\text { Non-Asian Imm. Shock (\% Recent Arrivals) }\end{array}$ & & & & & & & & & $\begin{array}{c}13.83 * * \\
(5.939) \\
-14.13 \\
(9.572)\end{array}$ & \\
\hline Vote Share for NZ First & 0.068 & 0.107 & 0.107 & 0.107 & 0.068 & 0.107 & 0.107 & 0.107 & 0.107 & 0.107 \\
\hline Electoral District FEs and AU Controls & No & No & No & Yes & No & No & No & Yes & Yes & Yes \\
\hline Controls for Opinions and Previous Voting & No & No & No & No & No & No & No & No & No & Yes \\
\hline R-squared & 0.027 & 0.055 & 0.058 & 0.083 & 0.025 & 0.052 & 0.055 & 0.077 & 0.067 & 0.277 \\
\hline F-Stat for Immigration Shock & & & & & 18.5 & 7.4 & 6.3 & 20.0 & & 19.8 \\
\hline $\begin{array}{l}\text { F-Stat for Structural Reform Shock } \\
\text { F-Stat Asian Immigration Shock } \\
\text { F-Stat Non-Asian Immigration Shock }\end{array}$ & & & & & 7.4 & 13.0 & 27.7 & 38.7 & $\begin{array}{l}26.8 \\
15.8 \\
49.7\end{array}$ & 38.4 \\
\hline Observations & 2,211 & 3,473 & 3,473 & 3,473 & 2,211 & 3,473 & 3,473 & 3,473 & 3,473 & 3,473 \\
\hline
\end{tabular}

$* * * \mathrm{p}<0.01, * * \mathrm{p}<0.05, * \mathrm{p}<0.1$. Robust standard errors in parentheses which allow for clustering at electorate district (ED) or labor market area (LMA) level. In all IV regressions, the two shock variables are instrumented using shift-share instruments as described in the paper. Shocks are measured at either the ED or LMA level depending on the regression. All regressions also include controls for gender, age-group, ethnicity, immigration status, education, employment status, religiousness, ( $\log$ ) household income, and urban/rural. Columns four, eight and nine includes additional control variables for the following area unit characteristics: (log) population, employment rate, unemployment rate, $(\log )$ mean income, gini index, and the proportion with school qualifications, vocational qualifications and university degrees, under 35 and over 65, female and Maori; and electoral district FEs. Column ten includes additional control variables for own ideological position, own opinion on the position of NZ First, trust in the different political parties, opinions about party leaders, opinions about the countries financial situation, immigration, taxes, redistribution, social conservatism and previous voting in 1990. 
Table 5: The Impact of Shocks on Voting for Other Poiltical Parties in 1996

\begin{tabular}{|c|c|c|c|c|c|c|}
\hline & NZ First & Labour & National & Far Left & Other Parties & Did Not Vote \\
\hline \multirow[t]{2}{*}{ Immigration Shock (\% Recent Arrivals) } & $4.779 * * *$ & 1.585 & -1.778 & -1.185 & -2.200 & -0.214 \\
\hline & $(1.526)$ & (1.654) & $(2.324)$ & (1.606) & $(1.360)$ & $(1.806)$ \\
\hline \multirow[t]{2}{*}{ Structural Reform Shock $(\% \Delta 1986$ to 19 ؛ } & $1.321 * * *$ & 0.330 & -0.741 & -0.457 & $-0.759 *$ & 0.169 \\
\hline & $(0.338)$ & $(0.456)$ & $(0.562)$ & $(0.383)$ & $(0.432)$ & $(0.411)$ \\
\hline Vote Share & 0.107 & 0.255 & 0.274 & 0.097 & 0.124 & 0.123 \\
\hline R-squared & 0.077 & 0.089 & 0.104 & 0.058 & 0.097 & 0.135 \\
\hline Observations & 3,473 & 3,473 & 3,473 & 3,473 & 3,473 & 3,473 \\
\hline
\end{tabular}

*** $\mathrm{p}<0.01, * * \mathrm{p}<0.05, * \mathrm{p}<0.1$. Robust standard errors in parentheses which allow for clustering at the LMA level. The two shock variables are measured at the LMA level and are instrumented using shift-share instruments as described in the paper. All regressions also include controls for gender, age-group, ethnicity, immigration status, education, employment status, religiousness, (log) household income, urban/rural; the following area unit characteristics: (log) population, employment rate, unemployment rate, $(\log )$ mean income, gini index, and the proportion with school qualifications, vocational qualifications and university degrees, under 35 and over 65, female and Maori; and electoral district FEs. 
Table 6: Do Economic Shocks Change People's Opinions and Ideology in 1996?

\begin{tabular}{|c|c|c|c|c|c|c|c|}
\hline & \multicolumn{2}{|c|}{ Immigration Shock } & \multicolumn{2}{|c|}{ Structural Reform Shock } & Mean DV & R-squared & Observations \\
\hline$\overline{\text { Own Ideology Left/Right Scale }}$ & -0.338 & $(5.144)$ & -1.531 & $(1.181)$ & 3.230 & 0.121 & 2,792 \\
\hline Socially Conservative & -0.322 & $(1.318)$ & $-0.665^{*}$ & $(0.379)$ & 0.241 & 0.267 & 3,473 \\
\hline Hostile to Immigration & $3.698 * * *$ & $(1.284)$ & 0.320 & $(0.325)$ & 0.728 & 0.118 & 3,473 \\
\hline Want to Reduce Taxes & 2.282 & $(1.931)$ & -0.0564 & $(0.557)$ & 0.636 & 0.066 & 3,473 \\
\hline In Favour of Redistribution & -1.748 & $(1.933)$ & $1.232 * *$ & $(0.497)$ & 0.608 & 0.112 & 3,473 \\
\hline Recent Policies Bad for the Country & 1.144 & $(1.635)$ & $0.860 * *$ & $(0.420)$ & 0.407 & 0.106 & 3,473 \\
\hline Importance of Immigration & -0.201 & $(1.225)$ & 0.365 & $(0.252)$ & 0.106 & 0.082 & 3,473 \\
\hline Importance of Unemployment & 1.162 & $(2.044)$ & $1.163 * *$ & $(0.548)$ & 0.606 & 0.088 & 3,473 \\
\hline Importance of Economic Growth & -0.0801 & $(2.142)$ & $-1.114^{*}$ & $(0.650)$ & 0.592 & 0.068 & 3,473 \\
\hline Importance of Tax Rates & 1.575 & $(2.044)$ & -0.529 & $(0.595)$ & 0.631 & 0.064 & 3,473 \\
\hline Importance of Education & 1.797 & $(1.672)$ & -0.617 & $(0.466)$ & 0.821 & 0.051 & 3,473 \\
\hline Importance of Social Welfare & 0.950 & $(1.715)$ & 0.113 & $(0.592)$ & 0.575 & 0.093 & 3,473 \\
\hline Importance of Defence & $3.280 *$ & (1.794) & 0.467 & $(0.382)$ & 0.132 & 0.084 & 3,473 \\
\hline Importance of Law and Order & $4.345 * *$ & $(2.179)$ & -0.299 & $(0.564)$ & 0.699 & 0.138 & 3,473 \\
\hline Strong Leader is Needed & $3.614 * *$ & $(1.533)$ & $0.896^{*}$ & $(0.523)$ & 0.613 & 0.099 & 3,473 \\
\hline Mistrust Toward Parties & $2.219 * *$ & $(1.107)$ & $0.652 * *$ & $(0.304)$ & 0.521 & 0.087 & 3,473 \\
\hline Better Feelings about Peters & 2.714 & $(1.891)$ & $0.966^{*}$ & $(0.534)$ & 0.279 & 0.129 & 3,473 \\
\hline Better Feelings about Clark & -0.422 & (2.119) & -0.222 & $(0.566)$ & 0.411 & 0.097 & 3,473 \\
\hline Better Feelings about Bolger & -1.771 & $(1.871)$ & -0.466 & $(0.557)$ & 0.290 & 0.096 & 3,473 \\
\hline
\end{tabular}

*** $\mathrm{p}<0.01, * * \mathrm{p}<0.05, * \mathrm{p}<0.1$. Robust standard errors in parentheses which allow for clustering at the LMA level. Each row presents the results from a separate regression. The two shock variables are instrumented using shift-share instruments as described in the paper. All regressions also include controls for gender, agegroup, ethnicity, immigration status, education, employment status, religiousness, (log) household income, urban/rural; the following area unit characteristics: (log) population, employment rate, unemployment rate, (log) mean income, gini index, and the proportion with school qualifications, vocational qualifications and university degrees, under 35 and over 65, female and Maori; and electoral district FEs. 
Table 7: Impact of Shocks on Demand for and Supply of Political Change

\begin{tabular}{lcccc}
\hline & \multicolumn{2}{c}{$\begin{array}{c}\text { Voted for MMP in 1993 } \\
\text { Referendum }\end{array}$} & \multicolumn{2}{c}{$\begin{array}{c}\text { NZF Fielded Electorate } \\
\text { Candidate in 1993 }\end{array}$} \\
\cline { 2 - 6 } & OLS & IV & OLS & IV \\
\hline Immigration Shock (\% Recent Arrivals) & 0.937 & $2.644^{* *}$ & -1.396 & -3.447 \\
& $(0.657)$ & $(1.346)$ & $(1.825)$ & $(2.904)$ \\
Structural Reform Shock $(\% \Delta 1986$ to 199 & 0.243 & 0.290 & -0.637 & -1.315 \\
& $(0.310)$ & $(0.851)$ & $(0.752)$ & $(2.373)$ \\
\hline Mean of dep variable & \multicolumn{3}{c}{0.467} & \multicolumn{3}{c}{0.872} \\
\hline R-squared & 0.045 & 0.042 & 0.061 & 0.045 \\
Observations & 2,211 & 2,211 & 2,211 & 2,211 \\
\hline *** p<0.01, ** $\mathrm{p}<0.05, *$ p $<0.1$. Robust standard errors in parentheses which allow for clustering at \\
electorate district $($ ED). In the IV regression, the two shock variables are instrumented using shift-share \\
instruments as described in the paper. All regressions also include controls for gender, age-group, \\
ethnicity, immigration status, education, employment status, religiousness, (log) household income, and \\
urban/rural.
\end{tabular}


Table 8: Long-Run Persistence of the Impact of Shocks on Voting for New Zealand First

\begin{tabular}{|c|c|c|c|c|c|c|c|c|}
\hline & 1999 & 2002 & 2005 & 2008 & 2011 & 2014 & 1999-2014 & $1999-2014$ \\
\hline Immigration Shock (\% Arrivals 1991 to 1996 ) & $\begin{array}{c}1.991 * \\
(1.138)\end{array}$ & $\begin{array}{c}-0.593 \\
(1.832)\end{array}$ & $\begin{array}{l}-0.734 \\
(1.030)\end{array}$ & $\begin{array}{c}-0.155 \\
(1.196)\end{array}$ & $\begin{array}{l}-0.727 \\
(1.102)\end{array}$ & $\begin{array}{c}5.331 * * \\
(2.716)\end{array}$ & $\begin{array}{c}0.435 \\
(0.709)\end{array}$ & $\begin{array}{l}-0.143 \\
(0.721)\end{array}$ \\
\hline Structural Reform Shock (\% $\Delta 1986$ to 1991) & $\begin{array}{c}0.535^{* * * *} \\
(0.198)\end{array}$ & $\begin{array}{l}0.621^{*} \\
(0.360)\end{array}$ & $\begin{array}{l}-0.179 \\
(0.471)\end{array}$ & $\begin{array}{l}-0.686 \\
(0.727)\end{array}$ & $\begin{array}{c}0.138 \\
(0.481)\end{array}$ & $\begin{array}{c}0.235 \\
(0.769)\end{array}$ & $\begin{array}{c}0.358 * * \\
(0.176)\end{array}$ & $\begin{array}{c}-0.0426 \\
(0.238)\end{array}$ \\
\hline Immigration Shock * NZ First in Opposition & & & & & & & & $\begin{array}{c}0.833 * * \\
(0.371)\end{array}$ \\
\hline Structural Reform Shock * NZ First in Opposition & & & & & & & & $\begin{array}{c}0.432 * * \\
(0.185)\end{array}$ \\
\hline Immigration Shock * Change in UE Rate & & & & & & & & $\begin{array}{l}-0.418 \\
(0.677)\end{array}$ \\
\hline Structural Reform Shock * Change in UE Rate & & & & & & & & $\begin{array}{c}-0.504 * \\
(0.291)\end{array}$ \\
\hline NZ First in Opposition & & & & & & & & $\begin{array}{l}0.0560 * \\
(0.0308)\end{array}$ \\
\hline Change in Unemployment Rate & & & & & & & & $\begin{array}{c}-0.121 * * \\
(0.0610)\end{array}$ \\
\hline Vote Share for NZ First & 0.042 & 0.083 & 0.044 & 0.033 & 0.043 & 0.075 & 0.053 & 0.053 \\
\hline R-squared & 0.069 & 0.061 & 0.057 & 0.079 & 0.073 & 0.166 & 0.034 & 0.035 \\
\hline F-Stat for Immigration Shock & 18.47 & 16.53 & 18.47 & 17.88 & 20.56 & 17.11 & 17.90 & 6.897 \\
\hline F-Stat for Income Shock & 29.26 & 18.48 & 11.33 & 7.952 & 7.483 & 7.941 & 17.45 & 8.196 \\
\hline Observations & 4,228 & 4,495 & 3,624 & 2,809 & 3,066 & 1,402 & 19,624 & 19,624 \\
\hline
\end{tabular}

*** $\mathrm{p}<0.01, * * \mathrm{p}<0.05, * \mathrm{p}<0.1$. Robust standard errors in parentheses which allow for clustering at the LMA level. The two shock variables are measured at the LMA level and are instrumented using shift-share instruments as described in the paper. All regressions also include controls for gender, age-group, ethnicity, immigration status, education, employment status, religiousness, (log) household income, urban/rural; the following area unit characteristics: (log) population, employment rate, unemployment rate, $(\log )$ mean income, gini index, and the proportion with school qualifications, vocational qualifications and university degrees, under 35 and over 65, female and Maori; and electoral district FEs. The last two columns also control for survey year FEs. 
Table 9: Heterogeneity in the Impact of Shocks on Voting for NZ First in 1996

\begin{tabular}{|c|c|c|c|c|c|c|c|c|c|c|}
\hline & Age $<35$ & Age $>65$ & Female & Low skilled & High Income & $\begin{array}{l}\text { University } \\
\text { Degree }\end{array}$ & $\begin{array}{c}\text { Non- } \\
\text { Employed }\end{array}$ & $\begin{array}{c}\text { Receiving } \\
\text { Benefits }\end{array}$ & $\begin{array}{c}\text { High Density } \\
\text { Areas }\end{array}$ & $\begin{array}{c}1986 \text { High } \\
\text { Immig. Areas }\end{array}$ \\
\hline Immigration Shock & $\begin{array}{c}4.471^{* * * *} \\
(1.607)\end{array}$ & $\begin{array}{c}4.775^{* * * *} \\
(1.521)\end{array}$ & $\begin{array}{c}4.920^{* * *} \\
(1.599)\end{array}$ & $\begin{array}{l}4.124 * * \\
(1.610)\end{array}$ & $\begin{array}{c}4.662 * * * \\
(1.540)\end{array}$ & $\begin{array}{c}4.592 * * * \\
(1.517)\end{array}$ & $\begin{array}{c}4.951^{* * * *} \\
(1.649)\end{array}$ & $\begin{array}{c}4.603 * * * \\
(1.528)\end{array}$ & $\begin{array}{l}3.477^{*} \\
(2.042)\end{array}$ & $\begin{array}{c}9.861^{* *} \\
(4.178)\end{array}$ \\
\hline Structural Reform Shock & $\begin{array}{c}1.424 * * * \\
(0.326)\end{array}$ & $\begin{array}{c}1.188^{* * *} \\
(0.337)\end{array}$ & $\begin{array}{c}1.353 * * * \\
(0.378)\end{array}$ & $\begin{array}{l}1.173 * * \\
(0.494)\end{array}$ & $\begin{array}{c}1.321 * * * \\
(0.352)\end{array}$ & $\begin{array}{c}1.370^{* * *} \\
(0.345)\end{array}$ & $\begin{array}{c}1.017 * * * \\
(0.340)\end{array}$ & $\begin{array}{c}1.237 * * * \\
(0.338)\end{array}$ & $\begin{array}{c}1.600 * * * \\
(0.418)\end{array}$ & $\begin{array}{c}1.271 * * * \\
(0.382)\end{array}$ \\
\hline Imm Shock * Interaction & $\begin{array}{c}0.650 \\
(1.297)\end{array}$ & $\begin{array}{c}1.427 \\
(1.614)\end{array}$ & $\begin{array}{l}-0.239 \\
(0.679)\end{array}$ & $\begin{array}{c}0.899 \\
(1.124)\end{array}$ & $\begin{array}{c}0.374 \\
(0.987)\end{array}$ & $\begin{array}{l}-0.629 \\
(1.060)\end{array}$ & $\begin{array}{c}0.507 \\
(0.807)\end{array}$ & $\begin{array}{c}1.063 \\
(1.360)\end{array}$ & $\begin{array}{c}-5.004^{* *} \\
(2.109)\end{array}$ & $\begin{array}{l}-10.35^{*} \\
(5.347)\end{array}$ \\
\hline SR Shock * Interaction & $\begin{array}{l}-0.449 \\
(0.556) \\
\end{array}$ & $\begin{array}{l}1.496 * * \\
(0.745) \\
\end{array}$ & $\begin{array}{l}-0.0692 \\
(0.374) \\
\end{array}$ & $\begin{array}{c}0.207 \\
(0.400) \\
\end{array}$ & $\begin{array}{r}-0.0857 \\
(0.474) \\
\end{array}$ & $\begin{array}{l}-0.447 \\
(0.533) \\
\end{array}$ & $\begin{array}{l}0.960 * * \\
(0.422) \\
\end{array}$ & $\begin{array}{c}0.490 \\
(0.627) \\
\end{array}$ & $\begin{array}{c}-2.206^{* *} \\
(0.938) \\
\end{array}$ & $\begin{array}{l}-1.015 \\
(0.989) \\
\end{array}$ \\
\hline R-squared & 0.077 & 0.074 & 0.077 & 0.078 & 0.079 & 0.077 & 0.074 & 0.076 & 0.079 & 0.080 \\
\hline Observations & 3,473 & 3,473 & 3,473 & 3,473 & 3.473 & 3,473 & 3,473 & 3,473 & 3,473 & 3,473 \\
\hline
\end{tabular}


Table 10: Do the Impact of Shocks on Voting for NZ First in 1996 Vary by People's Opinions?

\begin{tabular}{|c|c|c|c|c|c|c|c|c|}
\hline & $\begin{array}{l}\text { Left-right } \\
\text { ideology }\end{array}$ & $\begin{array}{c}\text { Socially } \\
\text { Conservative }\end{array}$ & $\begin{array}{l}\text { Hostile to } \\
\text { Immigration }\end{array}$ & $\begin{array}{c}\text { Want to } \\
\text { Reduce Taxes }\end{array}$ & $\begin{array}{c}\text { In Favor of } \\
\text { Redistribution }\end{array}$ & $\begin{array}{c}\text { Recent } \\
\text { Policies Bad } \\
\text { for the } \\
\text { Country }\end{array}$ & $\begin{array}{l}\text { Mistrust } \\
\text { Toward } \\
\text { Parties }\end{array}$ & $\begin{array}{l}\text { More Positive } \\
\text { Feelings about } \\
\text { Peters }\end{array}$ \\
\hline \multirow[t]{2}{*}{ Immigration Shock } & $6.257 * *$ & $4.616^{* * *}$ & $3.625 * *$ & $6.779 * * *$ & $5.017 * * *$ & $4.197 * * *$ & $4.006 * *$ & $3.474 * *$ \\
\hline & $(2.539)$ & $(1.530)$ & $(1.442)$ & $(1.769)$ & $(1.748)$ & $(1.495)$ & $(1.593)$ & $(1.381)$ \\
\hline \multirow[t]{2}{*}{ Structural Reform Shock } & $2.407 * * *$ & $1.287 * * *$ & 0.101 & $1.805 * * *$ & $0.693 *$ & $0.818 * * *$ & -0.106 & $0.555^{*}$ \\
\hline & $(0.680)$ & $(0.377)$ & $(0.353)$ & $(0.546)$ & $(0.369)$ & $(0.284)$ & $(0.376)$ & $(0.300)$ \\
\hline \multirow[t]{2}{*}{ Immigration Shock * Interaction } & -2.125 & 0.940 & 1.093 & $-2.994 * *$ & 0.226 & $2.099 *$ & 1.100 & 3.058 \\
\hline & $(1.648)$ & $(0.959)$ & $(1.159)$ & $(1.395)$ & $(1.167)$ & $(1.240)$ & $(1.601)$ & $(1.865)$ \\
\hline \multirow[t]{2}{*}{ Structural Reform Shock * Interaction } & $-1.338 * *$ & 0.272 & $1.655^{* * *}$ & -0.665 & $1.038 * *$ & $1.238^{*}$ & $2.603 * * *$ & $2.090 * * *$ \\
\hline & $(0.656)$ & $(0.522)$ & $(0.492)$ & $(0.555)$ & $(0.468)$ & $(0.701)$ & $(0.672)$ & $(0.788)$ \\
\hline R-squared & 0.075 & 0.079 & 0.095 & 0.079 & 0.084 & 0.089 & 0.101 & 0.215 \\
\hline Observations & 2,792 & 3,473 & 3,473 & 3,473 & 3,473 & 3,473 & 3,473 & 3,473 \\
\hline
\end{tabular}




\section{Appendix Table 1: Who Votes for Populist Parties in New Zealand and Europe}

\begin{tabular}{|c|c|c|c|c|}
\hline \multirow[b]{2}{*}{ Female } & \multicolumn{2}{|c|}{ NZ First in 1996} & \multicolumn{2}{|c|}{ Populist party in Europe from 2004 to 2019} \\
\hline & -0.006 & $(0.009)$ & $-0.011 * * *$ & $(0.001)$ \\
\hline Under 35 & $-0.050 * * *$ & $(0.015)$ & $-0.022 * * *$ & $(0.001)$ \\
\hline Over 65 & $0.043 * *$ & $(0.018)$ & -0.002 & $(0.002)$ \\
\hline Immigrant & $-0.035 * * *$ & $(0.013)$ & $-0.028 * * *$ & $(0.002)$ \\
\hline High Education & $-0.023 * *$ & $(0.010)$ & $-0.003 * *$ & $(0.001)$ \\
\hline Low Income & $0.036 * * *$ & $(0.011)$ & $0.007 * * *$ & $(0.001)$ \\
\hline NILF & -0.032 & $(0.026)$ & $-0.011 * * *$ & $(0.001)$ \\
\hline Unemployed & 0.022 & $(0.015)$ & -0.005 & $(0.003)$ \\
\hline Towns & 0.035 & $(0.022)$ & $0.003 * *$ & $(0.001)$ \\
\hline Rural & $0.069 * * *$ & $(0.026)$ & $0.005 * * *$ & $(0.001)$ \\
\hline Vote share & \multicolumn{2}{|c|}{0.107} & \multicolumn{2}{|c|}{0.057} \\
\hline R-squared & \multicolumn{2}{|c|}{0.072} & \multicolumn{2}{|c|}{0.095} \\
\hline Observations & \multicolumn{2}{|c|}{3,473} & \multicolumn{2}{|c|}{337,078} \\
\hline
\end{tabular}

*** $\mathrm{p}<0.01,{ }^{* *} \mathrm{p}<0.05, * \mathrm{p}<0.1$. NZF: data comes from NZES. Robust standard errors in parentheses which allow for clustering at the LMA level. The regression is weighted and includes Electorate FEs. Populist parties in Europe: data comes from the European Social Survey. Parties are defined as populist based on the 2014 and 2019 (candidate and already-established) waves of the Chapel Hill Expert Survey that include questions on the strength of the elite vs. the people narrative and its salience for each European party: the average is taken and a party is considered as populist if it gets a score higher than 7 over 10. Regression is weighted and includes country by year FEs. Included countries are: Austria, Belgium, Bulgaria, Cyprus, Croatia, Czechia, Denmark, Estonia, Finland, France, Germany, Greece, Hungary, Ireland, Italy, Latvia, Luxembourg, the Netherlands, Norway, Poland, Portugal, Serbia, Slovakia, Slovenia, Spain, Sweden, Switzerland, the UK. 


\section{Appendix Table 2: First-Stage Regressions for Impact of Shocks on Voting for NZ First in 1993 and 1996}

\begin{tabular}{|c|c|c|c|c|c|c|c|c|}
\hline $\begin{array}{l}\text { Year } \\
\text { Shocks Measured at: }\end{array}$ & \multicolumn{2}{|c|}{$\begin{array}{l}1993 \\
\mathrm{ED}\end{array}$} & \multicolumn{2}{|c|}{$\begin{array}{c}1996 \\
\text { ED }\end{array}$} & \multicolumn{2}{|c|}{$\begin{array}{l}1996 \\
\text { LMA }\end{array}$} & \multicolumn{2}{|c|}{$\begin{array}{r}1996 \\
\text { LMA } \\
\end{array}$} \\
\hline First Stage Dependent Variable & $\begin{array}{c}\text { Immigratio } \\
\mathrm{n} \text { Shock }\end{array}$ & $\begin{array}{l}\text { Structural } \\
\text { Ref Shock }\end{array}$ & $\begin{array}{c}\text { Immigratio } \\
\mathrm{n} \text { Shock }\end{array}$ & $\begin{array}{l}\text { Structural } \\
\text { Ref Shock }\end{array}$ & $\begin{array}{c}\text { Immigratio } \\
\text { n Shock }\end{array}$ & $\begin{array}{l}\text { Structural } \\
\text { Ref Shock }\end{array}$ & $\begin{array}{c}\text { Immigratio } \\
\mathrm{n} \text { Shock }\end{array}$ & $\begin{array}{l}\text { Structural } \\
\text { Ref Shock }\end{array}$ \\
\hline Predicted Immigration Shock (\% Recent Arrivals) & $\begin{array}{c}0.808^{* * *} \\
(0.150)\end{array}$ & $\begin{array}{l}-0.0514 \\
(0.367)\end{array}$ & $\begin{array}{c}0.627^{* * *} \\
(0.191)\end{array}$ & $\begin{array}{l}-0.461 \\
(0.282)\end{array}$ & $\begin{array}{c}0.310^{* *} \\
(0.147)\end{array}$ & $\begin{array}{c}-0.356^{* * * *} \\
(0.130)\end{array}$ & $\begin{array}{c}0.398 * * * \\
(0.0644)\end{array}$ & $\begin{array}{c}-0.440 * * * \\
(0.140)\end{array}$ \\
\hline Predicted Structural Reform Shock (\% $\Delta 1986$ to 1991) & $\begin{array}{c}0.616 * * * \\
(0.194) \\
\end{array}$ & $\begin{array}{c}2.242 * * * \\
(0.641) \\
\end{array}$ & $\begin{array}{c}0.476 * * \\
(0.189) \\
\end{array}$ & $\begin{array}{c}2.030 * * * \\
(0.681) \\
\end{array}$ & $\begin{array}{r}0.315 \\
(0.204) \\
\end{array}$ & $\begin{array}{c}1.925 * * * \\
(0.379) \\
\end{array}$ & $\begin{array}{c}0.0162 \\
(0.0390) \\
\end{array}$ & $\begin{array}{c}1.993 * * * \\
(0.255) \\
\end{array}$ \\
\hline $\begin{array}{l}\text { Mean Shock } \\
\text { Electoral District FEs and AU controls }\end{array}$ & \multicolumn{2}{|c|}{ No } & \multicolumn{2}{|c|}{ No } & \multicolumn{2}{|c|}{ No } & \multicolumn{2}{|c|}{ Yes } \\
\hline $\begin{array}{l}\text { R-squared } \\
\text { F-Stat for Excluded Instruments }\end{array}$ & $\begin{array}{c}0.653 \\
18.5\end{array}$ & $\begin{array}{c}0.321 \\
7.42\end{array}$ & $\begin{array}{c}0.530 \\
7.45\end{array}$ & $\begin{array}{l}0.329 \\
12.98\end{array}$ & $\begin{array}{c}0.637 \\
6.25\end{array}$ & $\begin{array}{l}0.494 \\
27.69\end{array}$ & $\begin{array}{l}0.948 \\
19.98\end{array}$ & $\begin{array}{l}0.789 \\
38.67\end{array}$ \\
\hline $\begin{array}{l}\text { Cragg-Donald F Statistic for Joint Excluded Instruments } \\
\text { Kleibergen-Paap LM Statistic - H0: Underidentified (P-valı } \\
\text { Observations }\end{array}$ & $\begin{array}{r}19 \\
0 \\
2,2\end{array}$ & $\begin{array}{l}.3 \\
0 \\
11\end{array}$ & $\begin{array}{c}31 \\
0 . \\
3,4\end{array}$ & $\begin{array}{l}.2 \\
73 \\
73\end{array}$ & $\begin{array}{c}53 \\
0 . \\
3,4\end{array}$ & $\begin{array}{l}.6 \\
43 \\
73\end{array}$ & $\begin{array}{c}84 \\
0 . \\
3,4\end{array}$ & $\begin{array}{l}.2 \\
0 \\
73\end{array}$ \\
\hline
\end{tabular}


